\title{
Evolutionary dynamics of Indo-European alignment patterns
}

\author{
Gerd Carling and Chundra Cathcart \\ Lund University | University of Zurich
}

This paper employs phylogenetic modeling to reconstruct the alignment system of Indo-European. We use a data set of categorical morphosyntactic features, which take states such as 'nominative-accusative,' 'active-stative', or 'ergative. We analyze these characters with a standard Bayesian comparative phylogenetic method, inferring transition rates between character states on the basis of a phylogenetic representation of the languages in the data. Using these rates, we then reconstruct the probability of presence of traits at the root and nodes of Indo-European. We find that the most probable alignment system for Proto-Indo-European is a nominative-accusative system, with low probabilities of neutral marking and ergativity in the categories lower in grammatical hierarchies (nouns, past). Using a test of phylogenetic signal, we find that characters pertaining to categories higher in hierarchies show greater phylogenetic stability than categories lower in hierarchies. We examine our results in relation to theories of Proto-Indo-European alignment as well as to general typology.

Keywords: historical linguistics, evolutionary linguistics, Proto-IndoEuropean, linguistic typology, grammar evolution, alignment, syntactic reconstruction

\section{Introduction}

\subsection{The study: An overview}

The current study aims to investigate the Indo-European alignment system using a Bayesian comparative phylogenetic method. In doing so, we are interested in several aspects of alignment reconstruction and change. First, we aim to reconstruct the most probable system of the root of the tree, which represents the Indo-European proto-language. Second, we aim to reconstruct the evolutionary dynamics of traits in the Indo-European phylogenetic tree, in order to conclude 
whether general, typological correlations play a role in the dynamics of alignment evolution over time. Finally, we aim to observe whether evolutionary trends in the tree reflect the attested and reconstructed change in the Indo-European family.

Reconstruction of Indo-European alignment has a long history in the scientific literature; both within the discipline of comparative-historical linguistics as well as within the discipline of typology (see \$1.3). An important aspect of this study is therefore to compare the result produced by our comparative phylogenetic model with different theories of alignment reconstruction. In previous literature on the topic, different models of reconstruction depend on the interpretation of attested language data, the reconstruction of paradigms, observed tendencies of change, as well as general typological implications. We discuss these arguments in the light of the results gained from our study. In addition, we observe the variable evolutionary dynamics of alignment traits. We discuss this variable behavior within the framework of general theories on grammatical hierarchies, in order to investigate whether there is a connection between general typological tendencies and the evolutionary behavior of alignment traits.

In this introduction, we describe the background of this study, providing an overview of the different models of reconstruction, which we label the comparative-historical, typological and comparative phylogenetic reconstruction methods (\$1.2). We give a literature overview on different reconstructions of Proto-Indo-European alignment, including the supporting arguments for the various models, in $§ 1.3$. We then discuss the issue of grammatical or marking hierarchies and frequency in alignment, as a background to a discussion on general typological tendencies and their relevance to the evolutionary dynamics of traits (\$1.4). In addition, we summarize, with respect to Indo-European specifically, different trends in alignment change in the family (\$1.5). In \$2, we first present our data, including targeted languages, the coding model of the original data set and the extraction and recoding model of the data used in the present paper (\$2.1). Second, we describe the Bayesian phylogenetic comparative method, including reconstruction of ancient states (\$2.2). Third, we describe the model used for assessing phylogenetic strength of characters $(\$ 2.3)$. In $\S 3$, we describe the results from various aspects, starting with an overview (\$3.1). Subsequently, we discuss probabilities at internal nodes of the tree where no data are observed, including the proto-language state $(\$ 3.2)$, probabilities at the proto-language state in the light of grammatical hierarchies (\$3.3), phylogenetic strength (\$3.4), and a summary of results (\$3.5). Section 4 contains a concluding discussion, where results are viewed in the light of general theories of language change as well as in contrast to various models of syntactic reconstruction. 


\subsection{Comparative, typological and phylogenetic models of reconstruction}

The model of syntactic reconstruction introduced in the 19th century is mainly based on reconstruction on the basis of grammatical morphemes, where forms and meanings are systematized so that comparative sets of paradigms can be reconstructed for a proto-language. Grammatical morphemes, like lexemes, can be reconstructed by the linguistic comparative method, hereafter simply referred to as the comparative method. However, establishing the meaning and syntactic function of reconstructed morphemes is more problematic, mainly because regularity and directionality in syntactic change is difficult to establish with certainty (cf. Barðdal 2014). In general, the comparative method cannot be applied to the reconstruction of syntactic features which are not bound by morphology, such as word order (Harris \& Campbell 1995; Harris 2008). Scholars take different positions on the reconstruction of syntactic features which are connected to morphology. Those who believe in a morphosyntactic reconstruction model argue that if a morpheme in combination with a syntactic function or a construction can be projected to the proto-language by the comparative method and has survived in a majority of languages, then there is reason to reconstruct it to the proto-language (Barðdal \& Eythórsson 2012; Barðdal 2014; Campbell \& Harris 2002: 615). Opponents to syntactic reconstruction often invoke the correspondence problem: we may reconstruct a pattern to an ancestor of several daughter languages carrying the same pattern, but in case of a disagreement we do not know enough about the directionality of syntactic change to reconstruct one variant over another (Roberts 2007:363-367; Walkden 2013). An additional problem is grammaticalization: features may continue to exist in languages, whereas the form is lost and recreated by grammaticalization (Hopper \& Traugott 2003:39-70). There are numerous examples, one being the case paradigm of Tocharian, which was almost entirely lost due to phonological change but which recreated several IndoEuropean cases, such as ablative, locative, dative, and genitive, by means of grammaticalization (Carling 2012).

A complementary method of syntactic reconstruction emerges from Joseph Greenberg's typological model (Greenberg 1966). This method accounts for language-internal implicational dependencies between features ("universals"). If these implications can be identified, based on a mass-based study of preferably unrelated languages, then these observations can be used as an argument for reconstructing a probable typology of a proto-language (Bickel 2007; Lehmann 1973, 1974; Nichols 1992, 1995, 1998). A problem of this model is the possible occurrence of language-internal conflicts with respect to "universal" dependencies. The Proto-Indo-European word order controversy is an example of this: a reconstruction of Proto-Indo-European comes out as inconsistent if it is based 
on the ancient languages (Friedrich 1975; Lehmann 1974; Watkins 1976; Winter 1984). In accordance with Greenbergian universals (Universal 24), an OV language is supposed to have Relative clause - Noun word order (Greenberg 1963; Lehmann 1973, 1974), which is the most common type in Hittite and Latin. However, in Sanskrit and Homeric Greek the most common order is Noun - Relative clause, which is inconsistent with OV, meaning that Indo-European has to be either OV or VO (following a consistency model) or reconstructed with an inconsistent order (Clackson 2007: 171-176; Hock 2013).

Diachronic typology combines reconstruction by the comparative method with typology. This model borrows methods and aims from cross-linguistic typology, and applies them to diachronic material, observing the typology of change rather than the typology of states (Hendery 2012:2-6). However, the problem of irregularity of patterns with respect to typological consistency, as well as the problem of reconstruction of syntax without cognacy, are continuing issues also in diachronic typology (Barðdal \& Eythórsson 2012; Barðdal 2014; Viti 2015:16-17).

Computational phylogenetic comparative models (Bowern 2018; Calude \& Verkerk 2016; Carling \& Cathcart 2021; Jäger 2019; da Silva \& Tehrani 2016) differ from the historical-comparative, typological and diachronic typological models. Most basic computational phylogenetic comparative models do not account for morphosyntactic reconstruction or assumptions regarding implicational dependencies between features. Rather, they use comparative data to infer information regarding the diachronic dynamics of individual features, and use these inferences to reconstruct most probable features for unobserved speech varieties (i.e., protolanguages) in a linguistic phylogeny. The probability of the presence of a morphological or syntactic feature at an ancestral proto-language is estimated on the basis of three key ingredients: (1) a representation of the phylogenetic relationship between the languages under study; (2) the distribution of the feature among the daughter languages; and (3) an evolutionary model of change (Cathcart et al. 2018; Dunn 2014; Greenhill et al. 2010; Maurits \& Griffiths 2014). The phylogenetic representation can consist of a handcrafted tree which incorporates subgroups based on the traditional comparative-historical method, or a sample of trees inferred from unrelated linguistic data (e.g., lexical data), using Bayesian methods from computational biology (Bouckaert et al. 2012; Chang et al. 2015; Gray \& Atkinson 2003). On the basis of the presupposed phylogenetic representation and the data observed for the languages in the tree (point 2 above), the model estimates the average rate of transition between traits of a categorical feature (e.g., SOV > SVO), under the assumption that the feature evolves according to a Continuous-time Markov process. This stochastic process can be used to simulate changes between states over continuous time intervals (point 3 above). For this type of model, a maximum likelihood estimate of the rates can be obtained; 
alternatively, we can sample from the posterior distributions of the rates via a Markov chain Monte Carlo or a similar technique for estimating parameter values for Bayesian models. Once evolutionary rates have been estimated, the probability of the presence of the feature in question can be estimated for internal nodes of the tree, including the root - the node ancestral to all of the attested languages in the sample (Felsenstein 2004; Yang 2014) (see further \$2.1).

\subsection{Indo-European alignment - reconstructions by comparative syntax}

Reconstruction of alignment systems has a long history in Indo-European comparative syntax, ultimately going back to the works of the Neogrammarians in the late 19th century. In the 2oth century, several alternative theories for Proto-IndoEuropean alignment reconstruction have been proposed. The Neogrammarians, e.g., Delbrück and Brugmann (Delbrück 1893, 1897, 1900), reconstruct an alignment system that is very close to the system found in most ancient Indo-European languages with the exception of Anatolian (which was not known to them). The alignment system described here is a completely nominative-accusative system, where the nominative codes the first argument (S/A) of intransitive and transitive verbs, and the accusative codes the second argument $(\mathrm{O})$ (Delbrück 1893:360-400; Meier-Brügger et al. 2010:401-404). However, even before the decipherment of Hittite in 1915 (Hrozný 1915), an alternative model of ergativity for Proto-Indo-European is proposed by Uhlenbeck (1901). This idea is based on the internal paradigmatic marking distribution in Proto-Indo-European, with the reconstruction of a case marking of ${ }^{*}$-s for transitive subject of animates (ergative), ${ }^{\star}$-m for transitive objects of animates (absolutive), and ${ }^{\star}$ - $\varnothing$ for inanimates (absolutive) (Pooth et al. 2019:246-248). The theory is later continued and developed by Vaillant (1936) and Soviet scholars of the 1970s (Gamkrelidze et al. 1995; Klimov 1973a, 1973b, 1974), who take the reconstruction one step further and suggest an active-stative alignment model. In this theory, the verb has no inherent transitivity (as in nominative-accusative and ergative models) and the alignment marking is based entirely on the semantics of the verbal core. The active-stative theory is continued by western scholars, such as Lehmann (1989), and recurs in a reviewed form in, e.g., Barðdal \& Eythórsson (2009, 2012), Bauer (2000), Drinka (1999), Matasović (2013), Pooth et al. (2019) and Schmidt (1979). The activestative and ergative theories, even though they differ in claims and rigidity, build on two main arguments. First, they focus on paradigmatic distinctions, which can be reconstructed for the proto-language on morphological grounds. The semantic and functional evaluation of these distinctions are identified as typologically frequent in languages of other types than the predominant Indo-European ones, i.e., nominative-accusative system, and hence support an alternative system of the 
proto-language, either ergative or active-stative. Second, they point at the existence of typological properties in ancient Indo-European languages, in particular Anatolian, but also in, e.g., Latin, which are proto-typical for active languages. These are seen as residuals of a pre-state that was entirely active-stative or ergative (i.e., Proto-Indo-European). Over time, the diachronic development from Proto-Indo-European to Anatolian and Early Italic resulted in a dominance of nominative-accusative structure.

The diachronic typology of the reconstructed active-stative or ergative paradigms, i.e., how they develop from active-stative via ergativity into nominativeaccusative (or from ergative to nominative-accusative) in a stratified Proto-Indo-European language and into sub-branches, is a vital part of the argument of active-stative theories (Schmalsteig 1981). In any case, an important part of the argument is that this transition was still in progress in the ancient branches, such as Anatolian and Italic (Bauer 2000). Therefore, at the core of the activestative and ergative theories we find the identification of properties of ProtoIndo-European which are observed to correlate with active-stative and ergative alignment (for a more detailed description, see Matasović (2013), together with references to relevant literature).

The most important arguments for alternative (i.e., ergative or active-stative) alignment theories are as follows:

1. THE ABSENCE OF A VERB FOR 'HAVE' IN PROTO-INDO-EUROPEAN AND THE USE OF A MIHI EST-CONSTRUCTION (Gamkrelidze et al. 1995:250; Klimov 1973a: 217; Lehmann 1989:115f). This is a property which is frequently found in active-stative and ergative languages, but it is also a common feature of languages of any type.

2. AN ASSUMED DISTINCTION BETWEEN ANIMATE - INANIMATE IN THE PROTOINDO-EUROPEAN NOMINAL PARADIGM. In the Proto-Indo-European noun, there is a ${ }^{*}$-os $/{ }^{*}$-om distinction in nominative/accusative of masculine/feminine (animate), whereas neuter (ancient inanimate) has an ending ${ }^{\star}-\varnothing /{ }^{*}-\mathrm{m}$, which makes no distinction between nominative and accusative (see Table 1). The distinction, which is mirrored by suppletion in the pronominal paradigm (Table 2), constitutes a core both to the ergative and active-stative theories (Drinka 1999; Gamkrelidze et al. 1995:245ff.; Kortlandt 1983; Pooth et al. 2019; Uhlenbeck 1901; Vaillant 1936). In addition, the distinction is present in the reconstructed noun class paradigm, which later emerges as a gender system (Villar 1984). An important argument here is the lack of gender and distinction between animate and inanimate in Anatolian (Luraghi 2011; Villar 1984). 
3. AN UNMARKED SUbJECT CASE AGAINST A MARKED OBJECT. This is another aspect of the reconstructed paradigm, which is seen as an indication of an ergative or active-stative Proto-Indo-European state. The marked ${ }^{*}$ snominative (in the masculine/feminine) is supposed to reflect an ergative case, against an unmarked absolutive (Bauer 2000: 44-46; Martinet 1962).

4. THE OCCURRENCE OF OBLIQUE SUBJECTS IN PROTO-INDO-EUROPEAN. Oblique subjects, or non-canonical (quirky) case marking, occur in several IndoEuropean languages, such as Germanic or Latin (Cennamo 20o9; Matasović 2013). By the syntactic reconstruction model of Construction Grammar these are traced back to Proto-Indo-European (Barðdal \& Eythórsson 2009, 2012). Non-canonical marking, in particular with stative verbs, is frequent in activestative and ergative languages and is therefore seen as an indication of an ergative system and a preceding active-stative system (Barðdal \& Eythórsson 2009; Matasović 2013; Pooth et al. 2019).

5. THE PRoto-Indo-European VERbal PARAdigm. Proto-Indo-European had a binary paradigm, with double setups of endings, which is seen as evidence in favor of active-stative structure in the proto-language (Gamkrelidze et al. 1995: 254ff.). Most important is the active vs. middle-passive paradigms, where the middle-passive is supposed to be related to the perfect tense by the endings (Lehmann 1989). In the active-stative theory, the ${ }^{*}$-mi (active), and ${ }^{\star}-\mathrm{h}_{2} \mathrm{e}$ (inactive) conjugation mark a semantic alignment system on the verb, and this is preserved in the - $m i$ and - hi paradigm setup in Anatolian (Gamkrelidze et al. 1995:254-276; Lehmann 1989; Meiser 2009). An important issue is the interpretation of verbal semantics of the $-m i$ and - $h i$ paradigms of Anatolian (Jasanoff 1978), the active and middle-passive voice (Luraghi 2012), and transitivity split in Hittite, visible in auxiliary formations as well as in clitics (Garrett 1996).

6. ALIENABLE/INALIENABLE POSSESSION AND INCLUSIVE/EXCLUSIVE PRONOUNS. This theory assumes that Proto-Indo-European had a distinction between alienable and inalienable possession, which is reflected in Hittite (Gamkrelidze et al. 1995: 251-252), as well as inclusive and exclusive pronouns (Gamkrelidze et al. 1995:253-254), reflected among others in the double forms of the plural of the pronoun ( ${ }^{*}$ wei- $/{ }^{*}$ mes- $)$. This distribution is considered to be an argument in favor of active-stative structure. In general, the arguments are considered to be weak (Matasović 2011).

As mentioned before, important arguments in favor of both the active-stative and ergative theories are supposed remnants of systems of this type in ancient IndoEuropean languages, most importantly the Anatolian - $m i$ and -hi paradigm setup 
as well as the presence of an ergative case marker (Garrett 1990, 1996) and the lack of gender (Matasović 2004; Villar 1984).

The active-stative and ergative theories are not accepted by all scholars (cf. Clackson 2007: 176-180). Most importantly, both theories imply a typologically ideal state, which is not preserved as such in any of the Indo-European branches. The described typological tendencies, which imply ergativity or active-stative typology (absence of 'have', nominal classification based on animacy, alienable/ inalienable possession, inclusive/exclusive pronouns), are not unique to activestative or ergative systems, but are also found frequently in nominative-accusative systems (Matasović 2011:2-3). Even languages with ergative systems, such as Hittite, are typically split-ergative rather than completely ergative (Goedegebuure 2013). The occurrence of ergativity in these languages typically reflects animacy hierarchies, where ergativity is restricted to the nominal system, whereas the pronominal system shows a nominative-accusative tendency (Silverstein 1976).

Several of the functional reconstructions of the ergative and active-stative paradigmatic reconstructions are weak. For instance, the formal contrast in Hittite between the $-m i$ and -hi conjugations is not reflected by a systematic difference in meaning (Jasanoff 2003:1-40), which makes it difficult to propose a semantic core for the Proto-Indo-European verb. Finally, yet importantly, the observed occurrences in ancient languages may be innovations under areal pressure from non-Indo-European languages, such as the Hittite ergative case (Clackson 2007; Garrett 1990: 178). These arguments lead some scholars to refute the active-stative and ergative theories purely on typological grounds (Rumsey 1987).

Table 1. Markedness in the Proto-Indo-European case paradigm, underlying the ergative and active-stative theories (Bauer 2000: 45; Szemerényi 1989:169)

\begin{tabular}{lll}
\hline & Masculine/Feminine & Neuter \\
\hline Nominative & ${ }^{*}-\varnothing /{ }^{*}-\mathrm{s}$ & ${ }^{*}-\varnothing /{ }^{*}-\mathrm{m}$ \\
Accusative & ${ }^{*}-\mathrm{m}$ & ${ }^{*}-\varnothing /{ }^{*}-\mathrm{m}$ \\
\hline
\end{tabular}

Table 2. Suppletion in the Proto-Indo-European pronominal paradigm (Bauer 2000: 45; Szemerényi 1989: 169)

\begin{tabular}{llll}
\hline & 1st person & 3rd person Masculine/Feminine & 3rd person Neuter \\
\hline Nominative & ${ }^{*}$ ego & ${ }^{*}$ so $/{ }^{*}$ sa & ${ }^{*}$ tod \\
Accusative & ${ }^{*}$ me & ${ }^{*}$ to & ${ }^{*}$ tod \\
\hline
\end{tabular}




\subsection{Marking and animacy hierarchies in alignment}

In languages with ergative or active-stative systems, referential marking hierarchies of grammatical relations, in particular with respect to animacy, influence the alignment coding (Bickel 2008; Comrie 1981:117ff.; Dixon 1994: 83ff.; Silverstein 1976). Few attested systems are entirely ergative or active-stative without accusative tendencies, and even accusative languages, such as Hittite, may display ergative tendencies (Garrett 1990; Goedegebuure 2013; Lopuhaä-Zwakenberg 2019). Marking hierarchies play a role in ergative and active-stative theories of Proto-Indo-European (Bauer 2000:44-47), in which synchronic patterns are seen as possible carriers of earlier stage residues of alternative (ergative, activestative) alignment. In general, semantic qualities as well as grammatical relations can underlie a marking hierarchy. Marking hierarchies are based on semantically conditioned factors, where grammatical categories higher in the animacy scale are also higher in the hierarchy (Comrie 1981:120-129), but marking hierarchies are also correlated with frequency and economy of feature types (Croft 2003:123; Witzlack-Makarevich \& Seržant 2018). Hierarchies can be observed by means of argument marking synchronically, such as subject and object, present and past. It is relatively common for a language to confirm marking hierarchies as a variation rather than as a default pattern (Verbeke \& De Clercq 2016; Witzlack-Makarevich \& Seržant 2018 for an overview) (see Table 3 for a list of marking hierarchies of relevance to alignment).

Table 3. Marking hierarchies of grammatical and semantic properties observed in the literature. After (Bickel 2008; Comrie 1981; Croft 2003; Dixon 1979; Malchukov 2015; Witzlack-Makarevich \& Seržant 2018)

\begin{tabular}{ll}
\hline Property type & Hierarchy \\
\hline Person & 1st person $<$ 2nd person $<$ 3rd person $<$ proper nouns \\
Animacy & human $<$ animate $<$ inanimate \\
Uniqueness & proper nouns $<$ common nouns \\
Number & singular $<$ plural $<$ dual \\
TAM & future $<$ present $<$ imperfect $<$ aorist $<$ perfect \\
\hline
\end{tabular}

Generally, the underlying principle of marking hierarchies is a tendency towards A (transitive subject) marking in the higher-ranking categories and a tendency towards $\mathrm{O}$ (transitive object) marking in the lower-ranking categories (Dixon 1994: 95ff.). This is a tendency which nevertheless has a substantial number of exceptions (Bickel 2008). Since grammatical hierarchies play a role in synchronic states of languages as well as in diachronic typology, we assume that they 
also play a role in the evolutionary dynamics of language change. We will return to the concept of grammatical hierarchies from the perspective of evolutionary reconstruction and the relevance to our results in $\$ 3.3$ and $\$ 3.4$.

\subsection{General trends in the family}

An important issue in alignment change is the principle of transition from one system to another, a phenomenon that we will consider from an evolutionary perspective. Diachronic change in alignment systems is a process that we are relatively well informed about: it has been observed historically and can be partly or completely reconstructed in several languages. Typically, a change from nominative-accusative to ergative and the reverse process, from ergative to nominative-accusative, involves a syntactic reinterpretation: in the case of accusative $\rightarrow$ ergative the process frequently involves a reinterpretation of the passive, in the case of ergative $\rightarrow$ accusative the process involves a reinterpretation of the antipassive. Further innovations include the emergence of periphrastic systems, emergence of new cases, or a generalization of marking patterns from one construction to others. There is a rich literature on the issue of morphosyntactic causes and grammaticalization pathways for the emergence of ergativity, based on observations from different languages (Dahl \& Stroński 2016a; Dahl 2016; Dench 1982; Dixon 1994:182-206; McGregor 2009:498-500; Verbeke \& De Cuypere 2009).

Looking at Indo-European alignment, there are two main transition tendencies, which have been observed from the earliest attested stages of a branch and further into the daughter languages. First, we have the alignment transition from the Old-Indo-Aryan nominative-accusative system into the (split) ergative and tripartite systems of New Indo-Aryan. Even though the pathways of change are not entirely clear, an important issue is the reinterpretation of the passive participle in - $t a$ (which agrees with $\mathrm{O}$ in transitive verbs and $\mathrm{S}$ by transitive verbs) into an ergative construction (Bubenik 2016; Dahl \& Stroński 2016b; Verbeke \& De Cuypere 2009). Second, we have the transition from a nominative-accusative system into a neutral system, which occurred in languages of the west (e.g., English, Celtic languages) but also occasionally in eastern languages (e.g., Pashto) (Brugman \& David 2014; Carling 2019:31-51; Ronan 2011). The process of this change, starting with a neutralization of the nominative - accusative distinction, can for instance be observed in Late Latin (Cennamo 2009). We will return to the issue of system transition from an evolutionary perspective and the relevance to our results in $\$ 3 \cdot 3-3 \cdot 4$. 


\section{Data, model and method}

\subsection{Data: Languages and coding models}

The data for the current study are extracted from the database DiACL (Carling 2017), subset DiACL/ Typology/ Eurasia (Carling et al. 2018), which contains typological properties of the Eurasian linguistic area. The coded features of the data describe alignment in terms of comparative concepts, following a "Comrian" model of generalization (Haspelmath 2011), similar to WALS (Dryer \& Haspelmath 2013). However, features are not described as properties, e.g., 'ergative,' 'nominative-accusative', etc., rather, they are defined as hierarchically organized features, which are Boolean (1/o) at the lowest level. This is more similar to the AUTOTYP and the multivariate model (Bickel \& Nichols 2002; Bickel 2010). For the current paper, we extract the hierarchical and binary coding of the data, which we recode into multistate characters (combinations of $1 / 0$ ), labeled as categorical features (see further below). The dataset contains data from most ancient Indo-European languages, something which increases the reliability of the comparative phylogenetic reconstruction (see further \$2.2). We use all 126 IndoEuropean languages available in the dataset (see Appendix 1) and extract features pertaining to the domain "Alignment" in the database (see Appendix 2 for a complete list). After the recoding, the data consists of multistate characters, labeled as categorical features, with variants, labeled traits (see Appendix 3). The raw dataset is openly available and can be downloaded from the DiACL database (Carling 2017). ${ }^{1}$

For the coding of alignment we follow the model of the data, which codes properties of grammatical relations according to how languages mark $S$ (intransitive subject), A (transitive subject), and O (transitive object). The model defines an alignment matrix based on argument properties (Bickel 2011; Dixon 1994, 2010), which identifies the basic aspects of accusative, ergative, active, and tripartite marking from the core arguments (Dahl \& Stroński 2016b). The basic alignment matrix of the data lists four correlations, $\mathrm{A}=\mathrm{O}, \mathrm{A}=\mathrm{Sa}, \mathrm{O}=\mathrm{So}$, and $\mathrm{Sa}=\mathrm{So}$ (Dixon 1994:23-48, 2010: 126ff.; Haspelmath 2011), which are used to describe the coding relations of $\mathrm{A}, \mathrm{S}$ and $\mathrm{O}$ with verbs of various transitivity (intransitive/ transitive) or semantic (active/stative, unergative/unaccusative) types ( $\mathrm{Sa} / \mathrm{So}$ ) (Table 4). These correlations are tested for differences in marking related to the word class of the first argument (noun/pronoun) and the tense of the verbal predicate (present progressive/past tense) (Table 5). A second coding variant tests

1. The recoded set as well as code used in this paper can be accessed via https://github.com /chundrac/evo-dyn-ie-align and https://zenodo.org/record/4118097. 
alignment properties with verbs, targeting marking differences in verbal agreement with reference to $S, A$, and $O$ (Table 6, Appendix 2).

The state combinations represent different alignment configurations, such as accusative, tripartite, ergative, active, or neutral marking (Table 7).

Table 4. Basic correlations in the data for defining alignment systems

\begin{tabular}{|c|c|}
\hline Variant & Explanation (for marking of $\mathrm{A}, \mathrm{S}$, and $\mathrm{O}$ ) \\
\hline $\mathrm{A}=\mathrm{O}$ & $\begin{array}{l}\text { The subject }(\mathrm{A}) \text { of a transitive verb bears the same marking as the object }(\mathrm{O}) \text { of a } \\
\text { transitive verb. }\end{array}$ \\
\hline $\mathrm{A}=\mathrm{Sa}$ & $\begin{array}{l}\text { The subject (A) of a transitive-active verb bears the same marking as the subject (S) of } \\
\text { an intransitive-active verb. }\end{array}$ \\
\hline $\mathrm{Sa}=\mathrm{So}$ & $\begin{array}{l}\text { The subject }(\mathrm{S}) \text { of an intransitive-active verb bears the same marking as the subject (S) } \\
\text { of an intransitive-stative verb. }\end{array}$ \\
\hline $\mathrm{So}=\mathrm{O}$ & $\begin{array}{l}\text { The subject }(\mathrm{S}) \text { of an intransitive-stative verb bears the same marking as the object }(\mathrm{O}) \\
\text { of a transitive-active verb. }\end{array}$ \\
\hline
\end{tabular}

Table 5. Model for coding of basic alignment types (by a matrix of properties) against word class of the first argument and tense of the predicate

\begin{tabular}{|c|c|c|c|}
\hline Matrix: & With & Word class of first argument: in & Tense: \\
\hline $\mathrm{A}=\mathrm{O}$ & & Noun & Present progressive \\
\hline $\mathrm{A}=\mathrm{Sa}$ & & Pronoun & Simple past \\
\hline \multicolumn{4}{|l|}{$\mathrm{O}=$ So } \\
\hline $\mathrm{Sa}=\mathrm{So}$ & & & \\
\hline
\end{tabular}

As mentioned above, we observe combinations of 1 and o as states of a multistate character, i.e., a categorical feature, in our data. To facilitate reading, we define these states as traits, to which we give a unique ID and a descriptive label, such as "Noun, Present progressive: Tripartite" (Table 7, Appendix 3). Nothing prevents the occurrence of illogical or impossible combinations, e.g., $\mathrm{A}=\mathrm{O}$ and $\mathrm{A}=\mathrm{Sa}$. Whenever illicit traits are found in the data or reconstructions, they turn out to be the result of mistakes in the coding. The illicit combinations at reconstructed states disappear as soon as we clean the coding in the attested languages.

In general, categorical features in attested languages can be defined by a relatively limited number of traits. The number of licit combinations, seen from a global perspective, could potentially be larger than in our sample. As an example, active-stative traits, which of course are perfectly licit, are absent in our data set. This has a straightforward explanation: we have extracted languages belonging to the Indo-European family, and the typological patterns reflect the attested 
Table 6. List of features of the alignment subsection (see Appendix 2 for the full set of binary feature variants)

\begin{tabular}{|c|c|}
\hline Categorical feature & Explanation \\
\hline Compare PROG-PAST & $\begin{array}{l}\text { What is the marking relation between subject and object in present } \\
\text { progressive and simple past? }\end{array}$ \\
\hline $\begin{array}{l}\text { Noun: Present } \\
\text { progressive }\end{array}$ & $\begin{array}{l}\text { In present progressive: how is the marking of subject and object of } \\
\text { nouns realized? }\end{array}$ \\
\hline Noun: Simple past & $\begin{array}{l}\text { In simple past: how is the marking of subject and object of nouns } \\
\text { realized? }\end{array}$ \\
\hline $\begin{array}{l}\text { Pronoun: Present } \\
\text { progressive }\end{array}$ & $\begin{array}{l}\text { In present progressive: how is the marking of subject and object of } \\
\text { pronouns realized? }\end{array}$ \\
\hline Pronoun: Simple past & $\begin{array}{l}\text { In present progressive: how is the marking of subject and object of } \\
\text { pronouns realized? }\end{array}$ \\
\hline $\begin{array}{l}\text { Reflexive pronoun in } \\
\text { transitive clause }\end{array}$ & What is the alignment of reflexive pronouns? \\
\hline Verb: Present progressive & In present progressive, how is alignment realized on the verb? \\
\hline Verb: Simple past & In simple past, how is alignment realized on the verb? \\
\hline
\end{tabular}

languages of this family. Figure 1 gives an overview of the distribution of the distribution of features and characters analyzed in this paper.

Table 7. Overview of state combinations of the data and the trait labels for a multistate character "Alignment type"

\begin{tabular}{lccccl}
\hline Type & $\mathrm{A}=\mathrm{O}$ & $\mathrm{A}=\mathrm{Sa}$ & $\mathrm{O}=\mathrm{So}$ & $\mathrm{Sa}=$ So & Alignment type \\
\hline (a) & 0 & 1 & 0 & 1 & nominative-accusative \\
(b) & 1 & 1 & 1 & 1 & neutral marking \\
(c) & 0 & 0 & 0 & 1 & tripartite \\
(d) & 0 & 0 & 1 & 1 & ergative \\
(e) & 0 & 1 & 1 & 0 & active \\
\hline
\end{tabular}

\subsection{The Bayesian phylogenetic comparative reconstruction model}

For each multistate character, the likelihood of a set of evolutionary transition rates between each pair of states under a given tree topology and observed data can be computed according to Felsenstein's Pruning Algorithm (Felsenstein 1981). We use a tree sample, which can be seen in Figure 2, that is generated as follows: we assume a fixed topology that agrees with received wisdom (Chang et al. 2015), 


\section{(a) Marking present progressive and simple past}

125

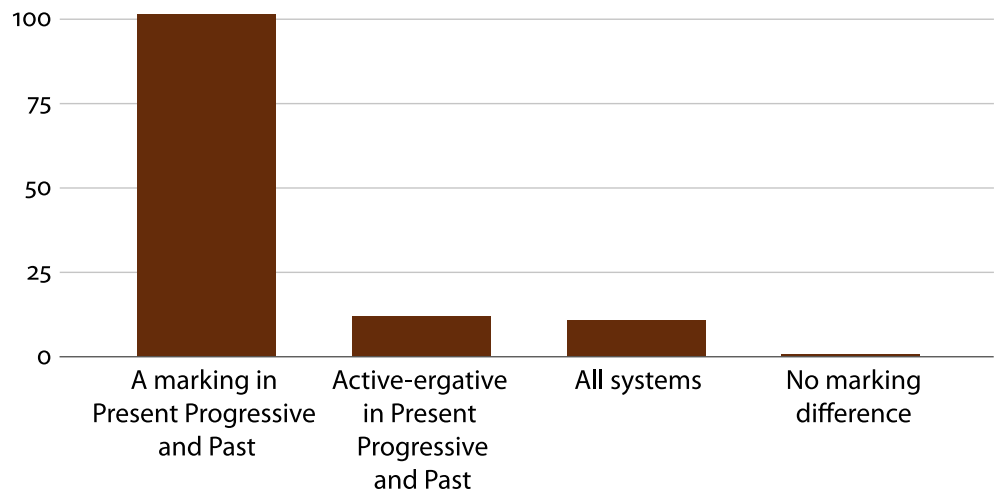

(b) Alignment by case marking

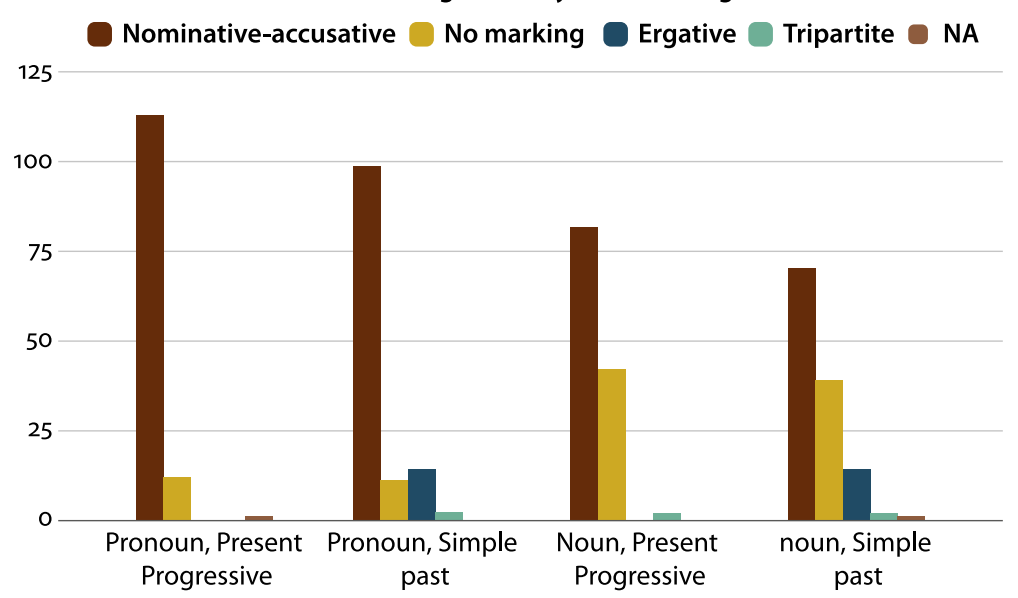


(c) Alignment types by verb

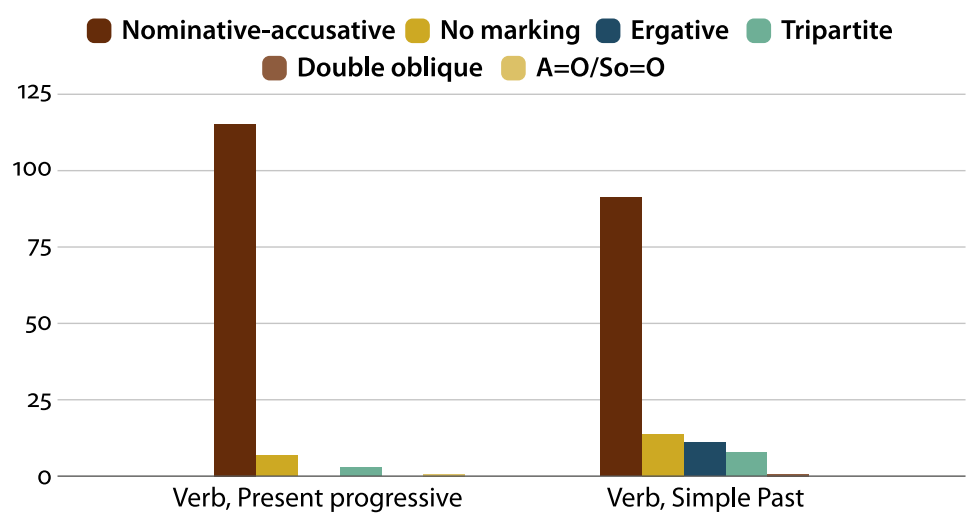

(d) Reflexive with $\mathrm{A}$ or $\mathrm{O}$

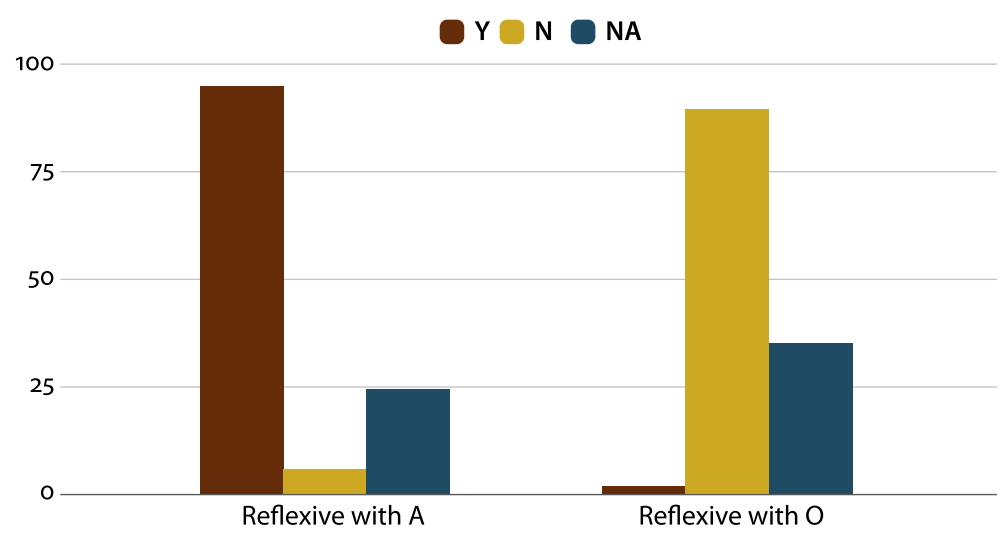

Figure 1. Bar plots summarizing the occurrence (in absolute numbers) of various trait types of some categorical features in the data, including Marking of Present progressive and Simple past (a), Alignment by case marking (b), Alignment by Verb (c), and Reflexive with $\mathrm{A}$ or $\mathrm{O}(\mathrm{d})$

and uniformly sample branch lengths from chronologically realistic intervals. This yields a tree with a root age uniformly distributed between 7000 and 6000 years BP. We scale branch lengths by dividing them by 1000 .

We infer transition rates using the No-U-Turn Sampler of RStan (Carpenter et al. 2017) to infer the posterior distributions of these rates for each tree in the sample. We run the sampler for 2000 iterations and discard the first half of samples as burn in; all parameters converge according to the potential scale reduction factor (Gelman \& Rubin 1992). We aggregate these posterior samples over the sample of trees. We place a Uniform $(0,5)$ prior over rates of change, constrain- 
ing our model such that transitions between two states do not occur more than 5 times within a given 1000 year period.

We estimate the probability of a given character state (i.e., a trait) at the root of the tree by randomly drawing evolutionary rates from the posterior sample, iteratively sampling a state at the root (Bollback 2006; Huelsenbeck et al. 2003; Nielsen 2002), and normalizing the counts for each sampled state to yield probabilities between $o$ and 1 . The results of the Bayesian evolutionary reconstruction are in the form of a probability of presence (between o and 1) of a state within a categorical feature at the root and nodes of the tree (see Appendix 3 and Figure 3 ). We evaluate the results in $\$ 3.3$.

In most cases, there is a clear result, with a high probability (0.70-1.00) for a specific state, and a low probability $(0.10-0.30)$ for the remaining states of a multistate character. In other instances, there is high uncertainty across reconstruction probabilities, indicating that no state in the character can be securely reconstructed.

\subsection{The model for assessing phylogenetic stability across characters}

In addition to the reconstruction process described in the previous section, we assess the phylogenetic stability of each character (e.g., categorical feature) in our data set using the method of Borges et al. (2018), which provides an estimation of the uncertainty of reconstructed states at internal nodes of the tree (cf. also Zhou \& Bowern 2015). ${ }^{2}$ Higher overall uncertainty or entropy corresponds to lower phylogenetic stability (in theory, a feature that varies across internal nodes of the tree but is reconstructed with high certainty at each node will also display low entropy). This method computes a linear version of the Shannon entropy on the basis of the probabilities of each of a character's $K$ states reconstructed for each node $n$ in the tree:

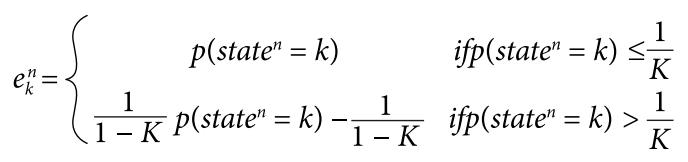

The entropy of each node can be obtained by summing over all $K$ states, yielding a normalized entropy measure:

2. The second author thanks Natalia Chousou-Polydouri for bringing this method to his attention. 

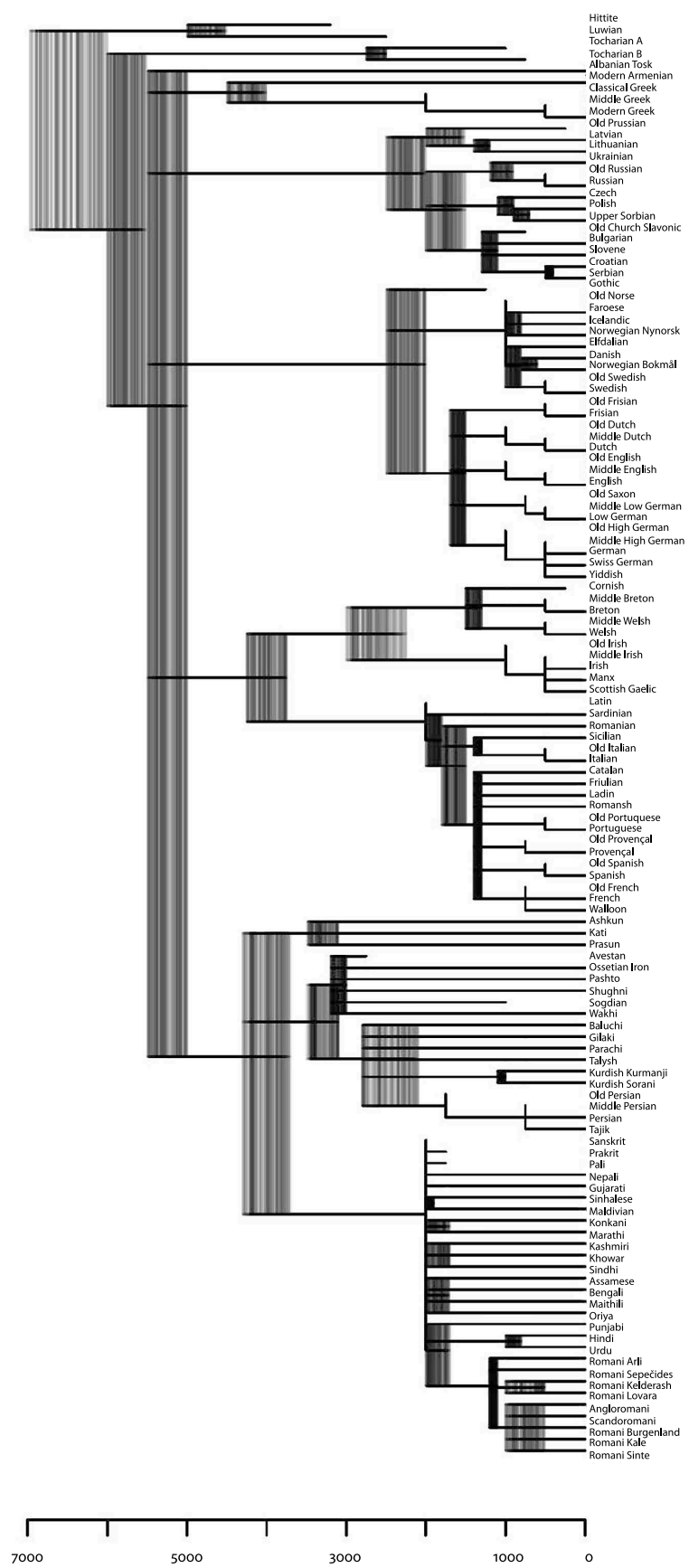

Figure 2. Phylogenetic reference tree for the Bayesian evolutionary reconstruction, based on a fixed tree topology 


$$
e_{n}=\sum_{k=1}^{k} e_{k}^{n}
$$

A small constant is added to zero values of $e_{n}$. Because values of $\boldsymbol{e}$ are defined on the $(0,1)$ interval, they can be modeled using the Beta distribution, assuming the following generative process:

$\lambda_{\mathrm{o}} \sim \operatorname{Gamma}(1,1) ; \alpha \sim$ Exponential $\left(\lambda_{\mathrm{o}}\right) ; \beta \sim \operatorname{Exponential}\left(\lambda_{\mathrm{o}}\right)$; for each internal node $n, e_{\mathrm{n}} \sim \operatorname{Beta}(\alpha, \beta)$

The parameters of the generative process can be inferred via Bayesian inference. We use the NUTS sampler of Rstan (with the same number of iterations and burn in as described above) to infer the posterior distributions of $\alpha$ and $\beta$. The $\delta$ statistic is computed for each sample by dividing $\beta$ by $\alpha$. Because Beta distributions with higher values of $\beta$ relative to $\alpha$ generate values closer to zero, higher values of $\delta$ correspond to lower overall entropy and higher phylogenetic stability. Distributions of $\delta$ computed from posterior distributions of $\alpha$ and $\beta$ for each character are found in Figure 4, in decreasing order (i.e., from highest to lowest phylogenetic stability). We evaluate the results in $\$ 3.4$.

\section{Results}

\subsection{Result overview}

In this section, we overview and evaluate the results of the evolutionary reconstruction. As outlined in the introductory section $(\$ 1.2-1.5)$, there are several potentially interesting aspects of our results, which we consider under different headings.

For each trait in the data, to which we have given a unique ID (A1-30) and a label to increase transparency, we reconstruct the probability of presence at the root (for the method, see \$2.2). Table 8 (columns from left to right) lists the multistate characters (i.e., categorical features) (1-9), the probabilities of presence for each trait at the root, the trait labels, and the trait ID numbers.

We highlight three different aspects of particular interest in our results, which have been mentioned in the introductory section $(\$ 1.2-1.5)$. The first aspect is the reconstructed trait probabilities at the proto-language state and the consequence of the results for the reconstruction of Proto-Indo-European morphosyn$\operatorname{tax}(\$ 3.2)$. The second aspect is the internal variation in probability levels between traits at the proto-language state, seen in the light of grammatical hierarchies in 
alignment (\$3.3). The third aspect is the phylogenetic strength of characters and the implication for the reconstruction and grammatical hierarchies $(\$ 3.4)$.

\subsection{Proto-language probabilities in the light of reconstruction by the comparative method and diachronic typology}

The results give a clear indication of nominative-accusative alignment (see Table 8). In the contrast between present and past, A marking is most frequent for both (Table 8: $1 \mathrm{~b}$ ). Nominative-accusative alignment is most probable with nouns as first argument in present progressive (Table $8: 2 \mathrm{~b}$ ), nouns as first argument in simple past (Table $8: 3 \mathrm{~b}$ ), pronouns as first argument in present progressive (Table 8:4a), pronouns in simple past (Table 8:5b), verbal marking in present progressive (Table 8:6b), and verbal marking in simple past (Table 8: $7 \mathrm{~b}$ ). We also note that the reflexive pronoun in transitive clauses aligns with the A (Table $8: 8 \mathrm{~b}$ ) and not with the $\mathrm{O}$ (Table 8:9a). These results indicate a total dominance of nominative-accusative alignment at the proto-language state. However, the differences in the degrees of probability are interesting. We notice that nominativeaccusative alignment is more likely in present progressive than in simple past, both for nouns and pronouns ( $2 \mathrm{~b}$ vs. $3 \mathrm{~b}, 4 \mathrm{a}$ vs. $5 \mathrm{~b}$ ), and nominative-accusative alignment is also more likely with pronouns as first argument than with nouns (4a vs. 2 b, 5 b vs. 3 b, see further $\$ 3.3$ ). The second most frequent type of alignment is neutral marking, followed by ergative (both with low probabilities).

Considering the reconstructions at internal nodes of the tree (Figure $3 \mathrm{a}-\mathrm{d}$ ) we see that the only noteworthy tendency is a change to neutral marking in Western sub-branches, such as Romance, Celtic and Germanic, and a change to tripartite and/or ergative marking in some of the Indo-Iranian sub-branches (Hindi-Urdu, Kurdish, Ashkun-Kati-Prasun). Again, the tendency is stronger in categories lower in grammatical hierarchies, i.e., in nouns and in simple past, and the tendency is almost absent in pronouns.

The active-stative or ergative alignment theories have low support in our reconstruction, which points to nominative-accusative dominance in nominal and pronominal case marking, in verbal conjugation (Table 8), and in the present/past distinction. Our result matches a canonical model of Indo-European alignment (cf. Meier-Brügger et al. 2010: 412). The only alternative theory with slight support in our data (for nouns only) is the neutral marking theory proposed by Hermann Hirt (1934: 76ff.), which never found support in the historicalcomparative scholarly community. This is mainly because attested historical change shows that case marking was often lost in later Indo-European languages. 
Table 8. Result overview of multistate characters (i.e., categorical features) (numbers 1-9) and traits (roman letters a-d) discussed in the text, including probability of presence of traits at the root (see \$3.2). The most probable traits are marked by $~$

\begin{tabular}{|c|c|c|c|}
\hline & Probability at root & Categorical features and trait labels & ID \\
\hline 1 & & Present-Past: Marking difference & \\
\hline $1 \mathrm{a}$ & 0.034475 & Present-Past: No marking difference & $\mathrm{A}_{1}$ \\
\hline$\neg 1 b$ & 0.765625 & Present-Past: A marking in Present progressive and Past & $\mathrm{A} 2$ \\
\hline $1 \mathrm{c}$ & 0.106325 & Present-Past: Active-ergative in Present progressive and Past & $\mathrm{A}_{3}$ \\
\hline $1 \mathrm{~d}$ & 0.093575 & Present-Past: All systems & $\mathrm{A}_{4}$ \\
\hline 2 & & Noun: Present progressive & \\
\hline $2 \mathrm{a}$ & 0.03415 & Noun, Present progressive: Tripartite & A5 \\
\hline$\rightarrow 2 b$ & 0.631175 & Noun, Present progressive: Nominative-accusative & A6 \\
\hline $2 \mathrm{C}$ & 0.334675 & Noun, Present progressive: Neutral marking & A7 \\
\hline 3 & & Noun: Simple past & \\
\hline $3 \mathrm{a}$ & 0.041225 & Noun, Simple past: Tripartite & A8 \\
\hline$\rightarrow 3 b$ & 0.526275 & Noun, Simple past: Nominative-accusative & A9 \\
\hline $3 \mathrm{c}$ & 0.122925 & Noun, Simple past: Ergative & A10 \\
\hline $3 \mathrm{~d}$ & 0.309575 & Noun, Simple past: Neutral marking & A11 \\
\hline 4 & & Pronoun: Present progressive & \\
\hline$\rightarrow 4 a$ & 0.90245 & Pronoun, Present progressive: Nominative-accusative & $\mathrm{A} 13$ \\
\hline $4 \mathrm{~b}$ & 0.09755 & Pronoun, Present progressive: Neutral marking & $\mathrm{A} 14$ \\
\hline 5 & & Pronoun: Simple past & \\
\hline $5 \mathrm{a}$ & 0.035225 & Pronoun, Simple past: Tripartite & A 15 \\
\hline$\rightarrow 5 b$ & 0.77255 & Pronoun, Simple past: Nominative-accusative & A16 \\
\hline $5 \mathrm{C}$ & 0.11405 & Pronoun, Simple past: Ergative & A18 \\
\hline $5 \mathrm{~d}$ & 0.078175 & Pronoun, Simple past: Neutral marking & A19 \\
\hline 6 & & Verb: Present progressive & \\
\hline $6 a$ & 0.036825 & Verb, Present progressive: Tripartite & $\mathrm{A} 24$ \\
\hline$\bullet 6 \mathrm{~b}$ & 0.8777 & Verb, Present progressive: Nominative-Accusative & A 25 \\
\hline $6 c$ & 0.05835 & Verb, Present progressive: Neutral marking & $\mathrm{A} 26$ \\
\hline 7 & & Verb: Simple past & \\
\hline $7 \mathrm{a}$ & 0.0794 & Verb, Simple past: Tripartite & $\mathrm{A} 27$ \\
\hline
\end{tabular}


Table 8. (continued)

\begin{tabular}{llll}
\hline & Probability at root & Categorical features and trait labels & ID \\
\hline 7b & 0.676275 & Verb, Simple past: Nominative-accusative & A28 \\
$7 \mathrm{c}$ & 0.089625 & Verb, Simple past: Ergative & A29 \\
$7 \mathrm{~d}$ & 0.114575 & Verb, Simple past: Neutral marking & A30 \\
8 & & Reflexive with Agent & \\
$8 \mathrm{a}$ & 0.04195 & Reflexive not with Agent & A20 \\
$\rightarrow$ 8b & 0.95805 & Reflexive with Agent & A21 \\
9 & & Reflexive with Object & \\
$\rightarrow$ 9a & 0.95445 & Reflexive not with Object & A22 \\
9b & 0.04555 & Reflexive with Object & A20 \\
\hline
\end{tabular}

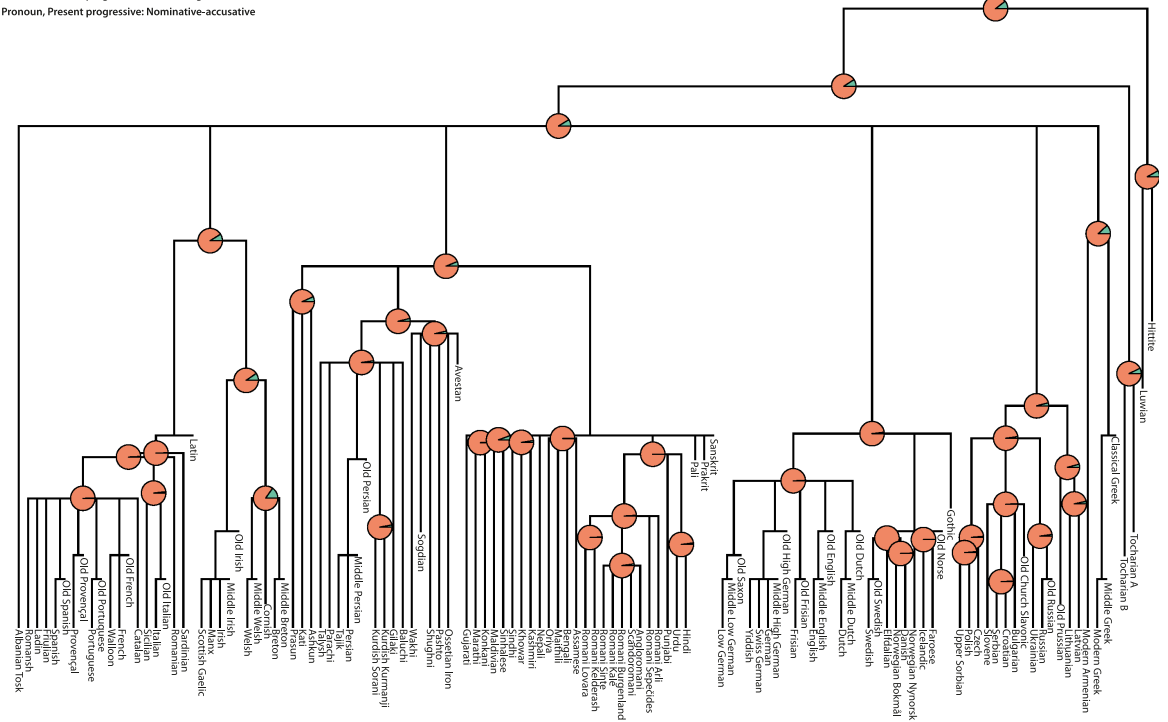

Figure 3a. Pie chart tree with reconstructions at hidden nodes for the categorical feature Pronoun: Present progressive

\subsection{Probability levels and grammatical hierarchies of alignment}

Here, we discuss the issue of grammatical or marking hierarchies in our results in the light of the received reconstructions for Proto-Indo-European, as well as the transition rates between states $(\$ 3.4)$. In the linguistic literature, typological generalizations about marking hierarchies typically refer to a synchronic variation or 
$\square$ Pronoun, Simple past: Ergative

P Pronoun, Simple past: No marking
Pronoun, Simple past: Nominative-accusative

Pronoun, Simple past: Tripartite

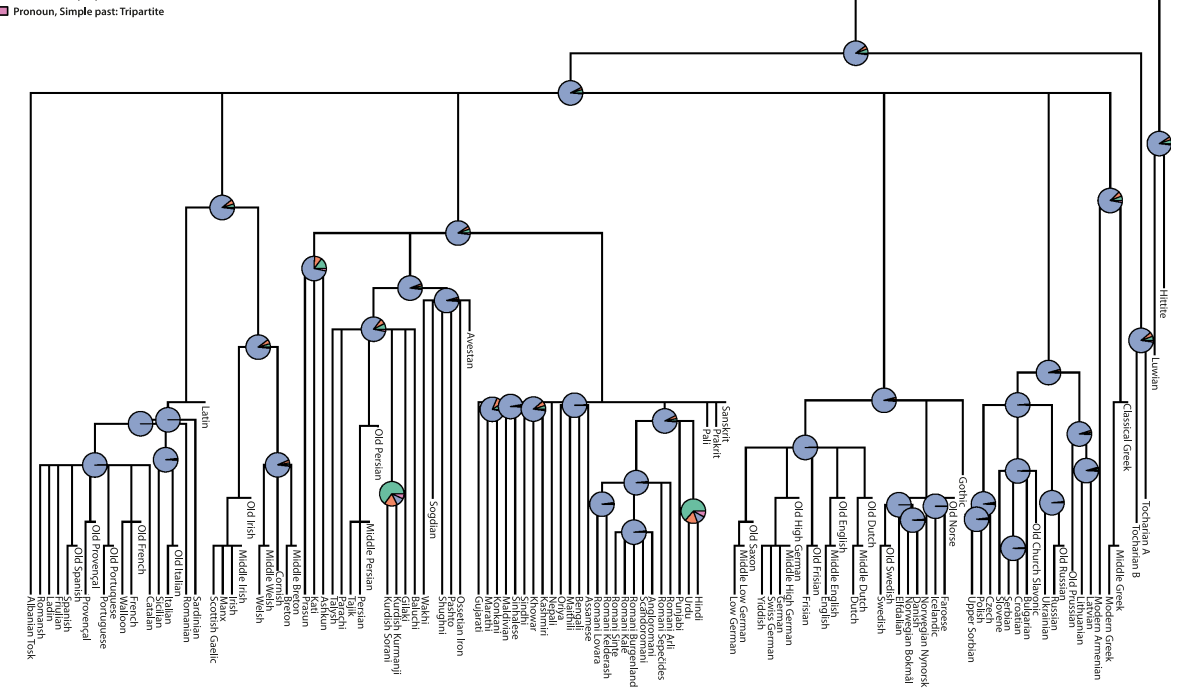

Figure $3 \mathbf{b}$. Pie chart tree with reconstructions at hidden nodes for the categorical feature Pronoun: Simple past

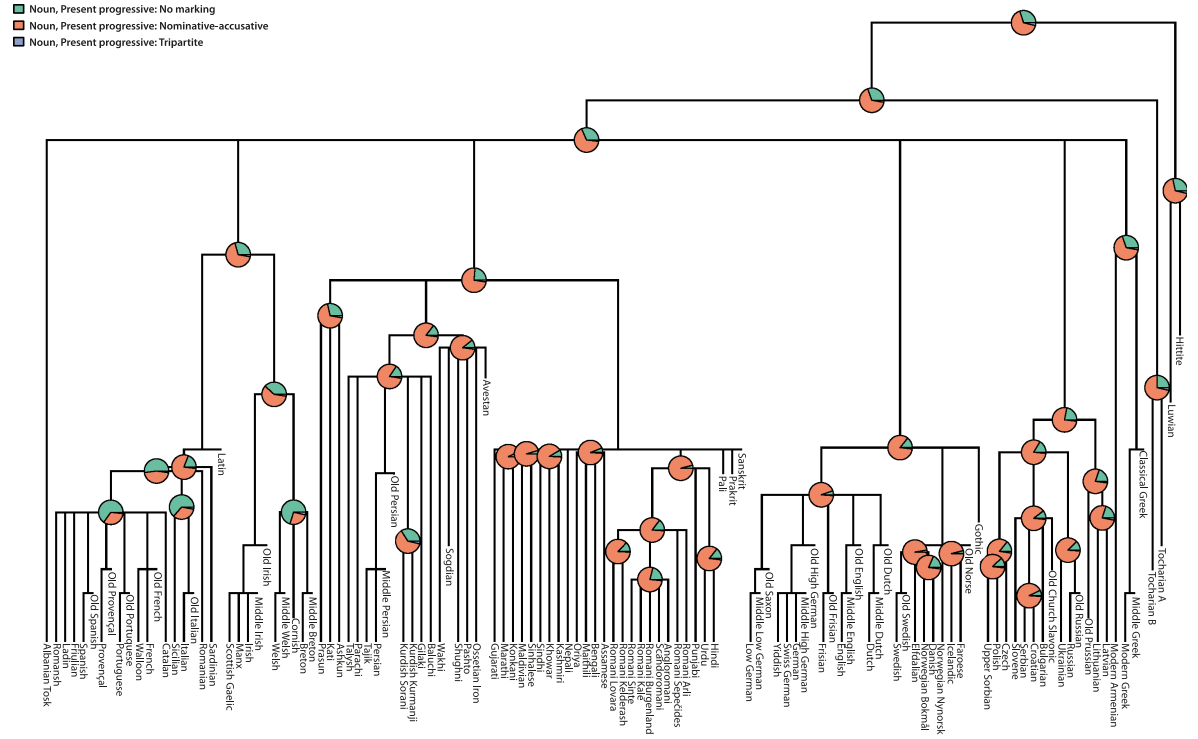

Figure 3c. Pie chart tree with reconstructions at hidden nodes for the categorical feature Noun: Present progressive 


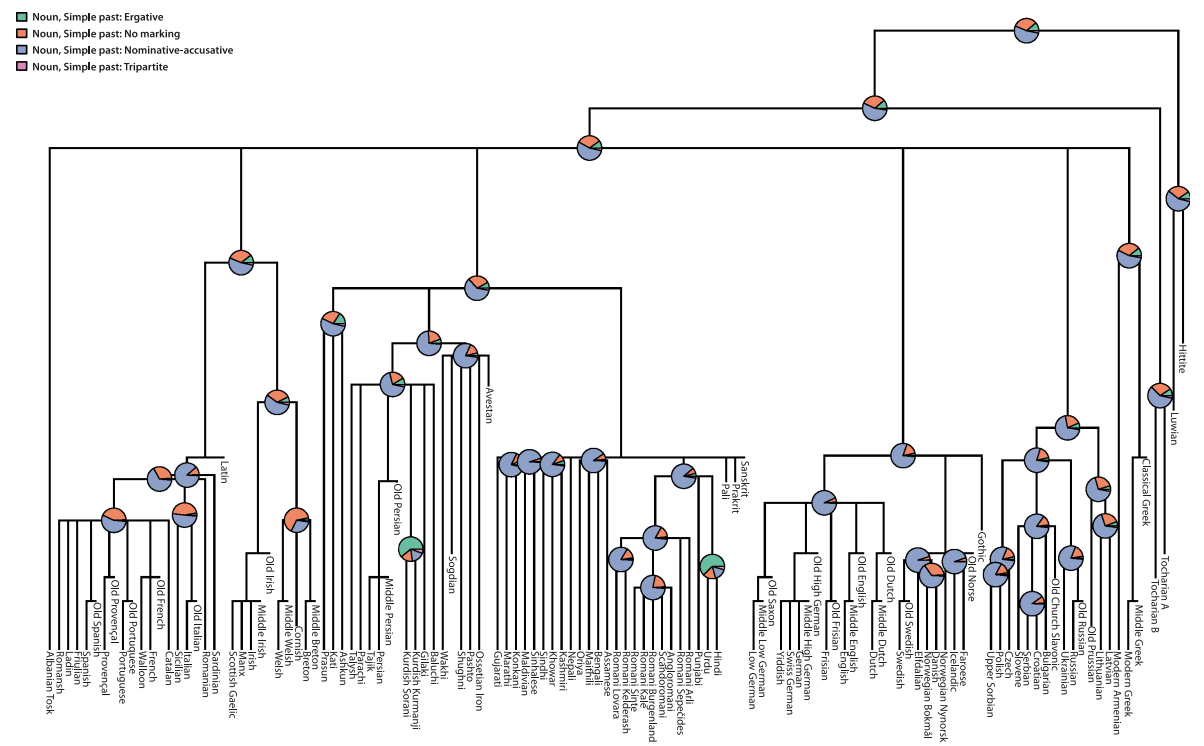

Figure 3d. Pie chart tree with reconstructions at hidden nodes for the categorical feature Noun: Simple past

deviation (Witzlack-Makarevich \& Seržant 2018). Our data is based on the generalization of a default marking in a synchronic state (Carling et al. 2018) and for this reason, it is noteworthy that our result at the root mirrors a language-internal variation pattern. Of the marking hierarchies observed in the literature (Table 3), two categories are of relevance to our category definitions: present progressive $<$ simple past, and pronoun < noun (additionally agent $<$ object). We observe, as described in the previous section, a systematic difference between these categories in our result (Figure 4).

In what way are these results of relevance to marking hierarchies? The answer is complex. If we consider the distribution of probabilities at the Proto-IndoEuropean level (Table 8, also \$3.2), we notice a tendency towards a clearer result, with a higher probability for the selected variant and a lower probability for other variants, in the grammatical categories of higher frequency and higher position in hierarchies (present, pronoun). On the contrary, we have a more unclear result, with lower probability for the selected variant and somewhat higher probabilities for other variants, in the categories of lower frequency and lower position in hierarchies (simple past, noun) (Table 3, Figure 4). In the present progressive by pronouns (Table 8:4), we have a very high (0.9) probability of nominative-accusative marking, and a low probability of neutral marking (0.097). The other systems (ergative, tripartite), are absent. In present progressive by nouns (Table 8:2), we have a medium probability, considerably lower than by pronouns, of nominative- 
accusative marking (o.63). Besides, we find neutral marking (0.33) and tripartite marking (0.034). In simple past (Table 8:3 and 5), we have a high probability of nominative-accusative marking ( 0.77$)$, which is lower than in present progressive by pronouns, and besides, we have ergative (0.11), neutral marking (0.078), and tripartite (0.035). Second, we notice that the ergative appears (with a low probability), but in the simple past only.

The results indicate a clear pattern of hierarchical organization, which mirrors the marking hierarchy as observed in synchronic states of languages ( $\$ 1.3)$.

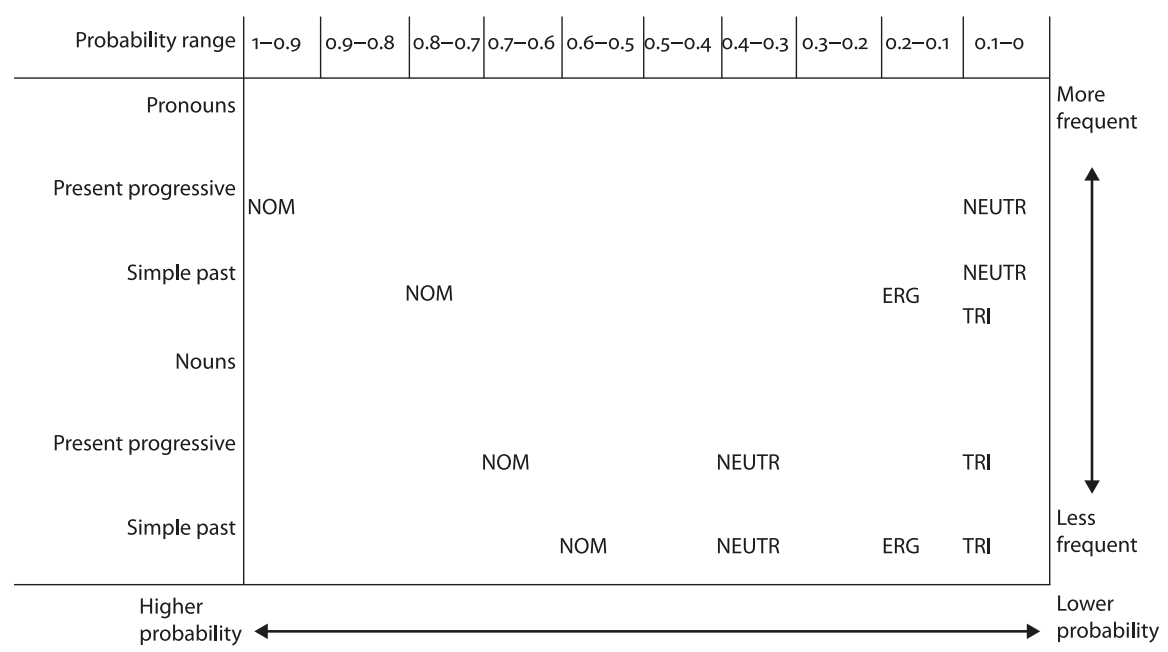

Figure 4. Overview of the ranges (divided into $10 \%$ segments) of the probabilities of the different tenses and word classes of alignment probabilities for Proto-Indo-European, contrasted to grammatical hierarchies of categories observed in languages. $\mathrm{NOM}=$ nominative-accusative, NEUTR = neutral marking, $\mathrm{ERG}=$ ergative, $\mathrm{TRI}=$ tripartite

\subsection{Phylogenetic strength}

We carry out the test for phylogenetic stability described in $\$ 2.3$ on our data. We test each character (i.e., categorical feature) according to the method of Borges et al. (2018), which provides an estimation of the uncertainty of reconstructed states at internal nodes of the tree. The method gives a statistic called $\delta$ for evaluating the degree of phylogenetic signal between a phylogeny and categorical traits. The higher the $\delta$ value, the higher the degree of phylogenetic signal between a given tree and a trait, i.e., the higher phylogenetic strength (Figure 5). In general, we find that $\delta$ values show the same sensitivity to the grammatical hierarchy as the results of the proto-language root, discussed in the previous section. Characters involving pronominal marking show higher stability and lower phylogenetic vari- 
ability than nouns. Within person categories such as pronoun and noun, the hierarchically higher tense category (i.e., present $<$ past) shows higher phylogenetic stability as well. Taken together, pronoun is stronger than verb, which is stronger than noun. Agent is stronger than object. The present - past distinction character is between the strong and the weak group. Noun characters are the weakest of all, far below both pronouns and verbs.

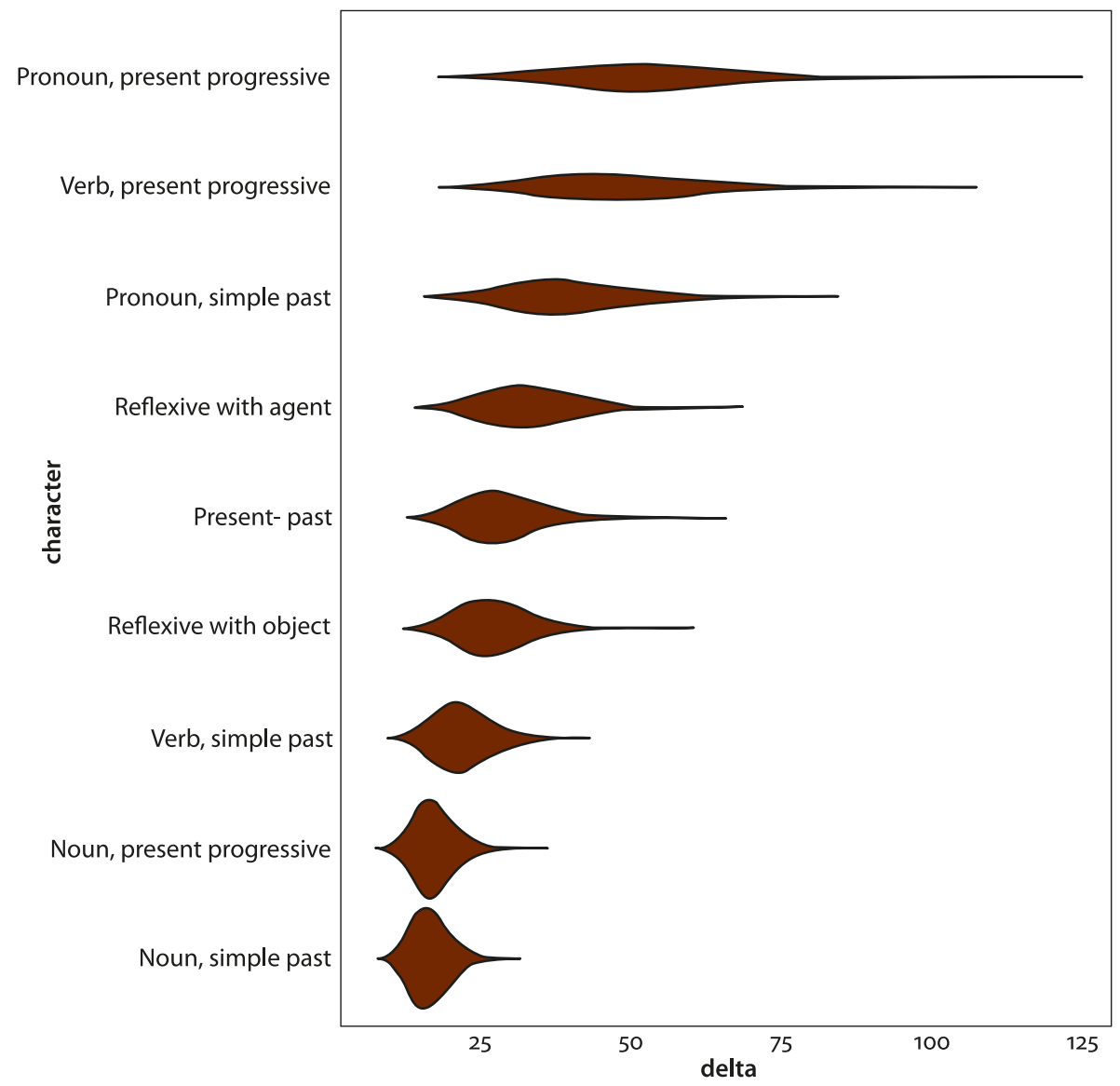

Figure 5. Delta distributions for each multistate character (i.e., categorical feature) of alignment marking, from highest to lowest phylogenetic stability

\subsection{Summary of results}

We have reconstructed the alignment system at the root of the Indo-European family tree. Alignment properties in our data are coded as multistate characters, which we define as categorical features with variants, called traits. We reconstruct 
the evolution of Indo-European alignment by means of a model, which estimates gains and losses of states of traits against a phylogenetic reference tree. The outcome is a probability of the presence of traits at the root of the tree, which we consider equal to Proto-Indo-European as reconstructed by the comparative method. The result of our analysis is a high probability of a nominative-accusative system, which shows tendencies of neutral marking and ergative (and tripartite to a very low degree) in the less frequent categories of grammar, lower in the marking hierarchies (present $<$ past, pronoun $<$ noun).

Second, we have estimated the overall stability of phylogenetic states within characters (i.e., categorical features) as a whole using a technique which estimates the uncertainty of state reconstructions at all internal nodes of the tree. We find that character stability appears to follow grammatical hierarchies as well, where features higher in grammatical hierarchies (more frequent, unmarked) have a higher stability and features lower in hierarchies (less frequent, marked) have a lower stability. The result, which organizes our categorical features from highest to lowest phylogenetic stability, confirms the observed grammatical hierarchies of pronoun < noun, present $<$ past, as well as agent $<$ object. Interestingly enough, we also find that the verb is consistently weaker than the pronoun, but stronger than the noun.

\section{Concluding discussion: Reconstructing the evolution of alignment}

The current study employs a Bayesian comparative phylogenetic model for reconstructing grammar, i.e., morphology and syntax. The data consist of comparative concepts, i.e., abstractions of grammar properties in attested languages, which are not connected to any morphological material that can be reconstructed by the comparative method. In this aspect, the model complements models of reconstruction, which use morphological reconstruction in combination with syntactic meaning reconstruction and diachronic typology (see \$1.3). The computational phylogenetic comparative method gives us valuable information about the general principles of grammar change of a family. The method takes attested grammar traits of all (or a representative amount of) languages of a family, calculates the transitions (gains and losses) for each trait of a categorical feature and returns an estimation of a probability of the trait at a proto-language state. The model is strictly phylogenetic and does not explicitly account for possible contact-induced change. A computational phylogenetic comparative model can be enhanced with so-called phylogeographic methods, where aspects of nearness in space and time and possible contact scenarios are taken into consideration (Cathcart et al. 2018). This is not done here: our model only accounts for the reconstruction and the 
phylogenetic strength of traits within the family. Further, our data is confined to one family, Indo-European. The disadvantage of using data from one family is that the generality of claims may be connected to uncertainty. In addition, any contactinduced changes involving languages from other families cannot be accounted for. However, Indo-European is provided with a higher number of ancient languages than most other families and is therefore very useful for reconstruction.

The methodology relies on a uniformitarian model in the sense that grammar processes of unattested periods are supposed to reflect changes of attested periods (Labov 1972; Walkden 2019). A precondition to the approach is to adapt a uniformity-of-state model, just as a uniformity-of-rate model, to language change. This means that we expect rules that govern language structure to be similar in the present and in the past, and all languages to reflect some basic universal principles (Croft 2003: 233; Walkden 2019). Accordingly, we also expect basic universal principles to impact the processes of change (Croft 2003: 272-279). In addition, the methodology has the shortcoming (or advantage) that it cannot reconstruct novel states. The estimations of probability at hidden nodes are based entirely on features that are attested in the data.

Considering these facts, it is remarkable how close our result approaches a canonical reconstruction model of Indo-European alignment, as presented already by the Neogrammarians (Delbrück 1893, 1897, 1900; Krahe et al. 1972; see Meier-Brügger et al. 2010). Despite the variation and change found at various states over the Indo-European family tree, the model reconstructs a synthetic, nominative-accusative alignment system of the proto-language. A fundamental aspect of evaluation is to consider how this result relates to syntactic reconstruction by the linguistic comparative method. Since our results are based on a computational phylogenetic comparative reconstruction of typological comparative concepts, they should be seen as complementary to results received by the linguistic comparative method, using morphological reconstruction and diachronic typology. However, the two reconstructions should not be considered as completely unrelated: if the two models of reconstruction (the linguistic comparative versus computational phylogenetic comparative model) give disparate results, something is fundamentally wrong with one of the reconstructions.

The alternative (ergative, active-stative) theories of Proto-Indo-European (see §1.1) assume profound typological changes from Early to Late Proto-IndoEuropean, which are concluded by internal reconstruction based on Proto-IndoEuropean paradigmatic correlations and a typological comparison with other, unrelated families (e.g., Caucasian). Let us scrutinize the arguments of the alternative theories in the light of the results achieved by the comparative phylogenetic reconstruction. The issue has several aspects. First, the chronological aspect of the dating and extension in time of the Indo-European proto-state (Bouckaert et al. 
2012; Chang et al. 2015; Meid 1975; Schlerath 1981). Second, the cyclic (or spiral) behavior of typological features (nominative-accusative $\rightarrow$ ergative or neutral; ergative or neutral $\rightarrow$ nominative-accusative) (Dixon 1997:182-206) of the type that we investigate here, including the timespan of these changes (Croft 2003:252; Haspelmath 2018; Hock \& Joseph 1996:183-184).

In the alternative models, Indo-European developed from an active-stative or ergative system into a nominative-accusative system during the period from early to late Proto-Indo-European or from Proto-Indo-European and continuing into the sub-branches (see \$1.3). As we have seen, the nominative-accusative alignment type is dominant in many contemporary and most historical states of the family (Figure 1) and is also reconstructed with the highest probability for the protolanguage state (Table 8). Neutral marking is reconstructed for the proto-language with a lower probability (nouns only, 0.3). The system of reconstruction inferred by our model is compatible with a trend where a nominative-accusative system is either eroding into a neutral system or occasionally developing into an ergative system. In both cases, the trend appears more pronounced in categories lower in grammatical hierarchies (past tense, noun, object), an interpretation supported by the fact that categories higher in grammatical hierarchies (present tense, pronoun, agent) show higher overall phylogenetic stability. Emergence of other systems are either marginal (tripartite) or non-existent (active-stative). The problem of alternative theories thus becomes somewhat of an Ockham's razor problem: why assume a system at the proto-language, which is concluded by exceptions within the attested languages (e.g., tendency to ergativity in Hittite, residues of animacy marking in Anatolian, non-canonical case marking in Latin)? The system is not attested as such in any of the surviving Indo-European languages (ergativity in Modern Indo-Aryan is clearly an innovation) and it is not supported by the general typological trend (keeping the nominative-accusative structure) of the past $6000-7000$ years in the family.

An interesting factor here is the confirmation of grammatical hierarchies at the proto-language state as well as in the evolutionary dynamics in the tree. Grammatical hierarchies have been extensively discussed in the linguistic literature, and the underlying causes for hierarchies, which often come out as a markedness distinction in languages, relate to animacy criteria as well as economy and frequency (Comrie 1981; Greenberg 1963, 1966; Hawkins 2004; Jaeger 2010). As we have seen in $\$ 3.3$, the distribution of probabilities at the root in higher categories (pronoun $<$ noun, present $<$ past) is clearer, with a higher probability of the preferred variant over the non-preferred variant (Figure 1). In addition, alternative systems (ergative, tripartite) appear only in the categories lower in the hierarchy (noun, past). The distribution of phylogenetic strength confirms this tendency, where categories higher in grammatical hierarchies consistently have higher phylogenetic 
strength, whereas categories lower in grammatical hierarchies have a lower phylogenetic strength (Figure 4) (Haiman 1983; Haspelmath 2008; cf. Jaeger 2010). In this respect, our results are more in line with the theoretical implications by, e.g., Rumsey (1987), Villar (1984), who argue, following Silverstein (1976), that the ergative (and active-stative) theories are untenable "for strictly comparative reasons as for reasons drawn from the normal behavior of ergative, accusative, and split systems" (Villar 1984: 175).

In sum, our computational phylogenetic comparative reconstruction confirms Proto-Indo-European as a nominative-accusative language with a slight tendency to neutral marking and ergativity in the categories lower in grammatical hierarchies (past, noun). This goes for alignment marked both by cases as well as by the verb. The nominative-accusative marking is consistent with respect to tense (present, past) and reflexives align with the agent. Phylogenetically, pronoun is stronger than verb, which is stronger than noun. Agent is stronger than object, and present is stronger than past. In all, noun categories are the weakest of all characters. The result confirms that the dynamics of language change is both individual and variating, as well as subjugated to universal principles of typology, such as frequency and economy. The result also confirms that a proto-language may be just as varying as any attested or spoken language.

\section{Funding}

The research was supported by the project CHRONOS - Chronology of Roots and Nodes of Family Trees (MAW 2017.0050) from the Marcus and Amalia Wallenberg Foundation.

\section{Acknowledgements}

We thank our colleagues Arthur Holmer, Filip Larsson, and Niklas Erben Johansson for input on data and coding. We thank the anonymous reviewers for their suggestions. We also thank Simon Devylder and Johannes Dellert for proofreading (French/German translations).

\section{References}

Barðdal, Jóhanna. 2014. Syntax and syntactic reconstruction. In Claire Bowern \& Bethwyn Evans (eds.), The Routledge handbook of historical linguistics, 343-373. London/New York: Routledge.

Barðdal, Jóhanna \& Thórhallur Eythórsson. 2009. The origin of the oblique subject construction: An Indo-European comparison. In Vit Bubenik, John Hewson \& Sarah Rose (eds.), Grammatical change in Indo-European languages, 179-193. Amsterdam/Philadelphia: John Benjamins. https://doi.org/10.1075/cilt.305.19bar 
Barðdal, Jóhanna \& Thórhallur Eythórsson. 2012. Reconstructing syntax: Construction grammar and the Comparative Method. In Hans C. Boas \& Ivan A. Sag (eds.), Sign-based construction grammar, 257-308. Stanford: Center for the Study of Language and Information.

Bauer, Brigitte. 200o. Archaic syntax in Indo-European: The spread of transitivity in Latin and French (Trends in linguistics. Studies and monographs 25). Berlin: Mouton de Gruyter. https://doi.org/10.1515/9783110825992

Bickel, Balthasar. 2007. Typology in the 21st century: Major current developments. Linguistic Typology 11(1). 239-251. https://doi.org/10.1515/LINGTY.2007.018

Bickel, Balthasar. 2008. On the scope of the referential hierarchy in the typology of grammatical relations. In Greville G. Corbett \& Michael Noonan (eds.), Case and grammatical relations. Studies in honor of Bernard Comrie, 191-210. Amsterdam/ Philadelphia: John Benjamins. https://doi.org/10.1075/tsl.81.09ont

Bickel, Balthasar. 2010. Capturing particulars and universals in clause linkage: A multivariate analysis. In Isabelle Bril (ed.), Clause linking and clause hierarchy: Syntax and pragmatics, 51-101. Amsterdam - Philadelphia: John Benjamins. https://doi.org/10.1075/slcs.121.03bic

Bickel, Balthasar. 2011. Grammatical relations typology. In Jae Jung Song (ed.), The Oxford handbook of linguistic typology, 399-444. Oxford: Oxford University Press.

Bickel, Balthasar \& Johanna Nichols. 2002. Autotypologizing databases and their use in fieldwork. In Peter Austin, H. Dry \& P. Wittenburg (eds.), Proceedings of the International LREC Workshop on Resources and Tools in Field Linguistics, Las Palmas. Nijmegen: ISLE and DOBES.

Bollback, J.P. 2006. SIMMAP: Stochastic character mapping of discrete traits on phylogenies. BMC Bioinformatics 7, 88 (2006). https://doi.org/10.1186/1471-2105-7-88

Borges, Rui, João Paulo Machado, Cidália Gomes, Ana Paula Rocha \& Agostinho Antunes. 2018. Measuring phylogenetic signal between categorical traits and phylogenies. Bioinformatics 2018. 1-8.

Bouckaert, Remco, Philippe Lemey, Michael Dunn, Simon J. Greenhill, Alexander V. Alekseyenko, Alexei J. Drummond, Russell D. Gray, Marc A. Suchard \& Quentin D. Atkinson. 2012. Mapping the origins and expansion of the Indo-European language family. Science 337(6097). 957-960. https://doi.org/10.1126/science.1219669

Bowern, Claire. 2018. Computational phylogenetics. Annual Review of Linguistics 4(1). 281-296. https://doi.org/10.1146/annurev-linguistics-011516-034142

Brugman, Claudia \& Anne David. 2014. Descriptive grammar of Pashto and its dialects. Berlin/New York: Mouton De Gruyter.

Bubenik, Vit. 2016. On the establishment of ergative alignment during the Late Middle IndoAryan period. In Eystein Dahl \& Krzysztof Stronski (eds.), Indo-Aryan ergativity in typological and diachronic perspective, 109-132. Amsterdam/Philadelphia: John Benjamins. https://doi.org/10.1075/tsl.112.04bub

Calude, Andreea S. \& Annemarie Verkerk. 2016. The typology and diachrony of higher numerals in Indo-European: A phylogenetic comparative study. Journal of Language Evolution 1(2). 91-108. https://doi.org/10.1093/jole/lzwoo3

Campbell, Lyle \& Alice C. Harris. 2002. Syntactic reconstruction and demythologizing 'Myths and the Prehistory of Grammars'. Journal of Linguistics 38(3). 599-618. https://doi.org/10.1017/So022226702001706

Carling, Gerd. 2012. Development of form and function in a case system with layers: Tocharian and Romani compared. Tocharian and Indo-European Studies 13. 57-76. 
Carling, Gerd. 2017. DiACL - Diachronic Atlas of Comparative Linguistics Online. https://diacl .ht.lu.se/

Carling, Gerd. 2019. Mouton atlas of languages and cultures. Vol. 1: Europe and West, Central and South Asia. Berlin/Boston: Mouton de Gruyter. https://doi.org/10.1515/9783110367416

Carling, Gerd \& Chundra Cathcart. 2021. Reconstructing the evolution of Indo-European grammar. Language.

Carling, Gerd, Filip Larsson, Chundra A. Cathcart, Niklas Johansson, Arthur Holmer, Erich Round \& Rob Verhoeven. 2018. Diachronic Atlas of Comparative Linguistics (DiACL) - A Database for Ancient Language Typology. PLOS ONE 13(10). https://doi.org/10.1371/journal.pone.0205313

Carpenter, Bob, Andrew Gelman, Matthew D. Hoffman, Daniel Lee, Ben Goodrich, Michael Betancourt, Marcus Brubaker, Jiqiang Guo, Peter Li, \& Allen Riddell. 2017. Stan: A Probabilistic Programming Language. Journal of Statistical Software 76(1). 1-32. https://doi.org/10.18637/jss.v076.io1

Cathcart, Chundra, Gerd Carling, Filip Larsson, Niklas Johansson \& Erich Round. 2018. Areal pressure in grammatical evolution. Diachronica 35(1). 1-34. https://doi.org/10.1075/dia.16035.cat

Cennamo, Michaela. 2009. Argument structure and alignment variations and changes in Late Latin. In Jóhanna Barðdal \& Shobhana Lakshmi Chelliah (eds.), The rope of semantic, pragmatic, and discourse factors in the development of case, 307-346.

Amsterdam/Philadelphia: John Benjamins. https://doi.org/10.1075/slcs.108.17cen

Chang, Will, Chundra Cathcart, David Hall \& Andrew Garrett. 2015. Ancestry-constrained phylogenetic analysis supports the Indo-European steppe hypothesis. Language, 91(1). 194-244. https://doi.org/10.1353/lan.2015.0005

Clackson, James. 2007. Indo-European linguistics: An introduction (Cambridge textbooks in linguistics). Cambridge: Cambridge University Press. https://doi.org/10.1017/CBO9780511808616

Comrie, Bernard. 1981. Language universals and linguistic typology: Syntax and morphology. Oxford: Blackwell.

Croft, William. 2003. Typology and universals (Cambridge textbooks in linguistics). Cambridge: Cambridge University Press.

Dahl, Eystein. 2016. The origin and development of the Old Indo-Aryan predicated -tá construction. In Eystein Dahl \& Krzysztof Stronski (eds.), Indo-Aryan ergativity in typological and diachronic perspective, 61-108. Amsterdam: John Benjamins. https://doi.org/10.1075/tsl.112.03dah

Dahl, Eystein \& Krzysztof Stroński. 2016a. Ergativity in Indo-Aryan and beyond. In Eystein Dahl \& Krzysztof Strónski (eds.), Indo-Aryan Ergativity in typological and diachronic perspective, 1-37. Amsterdam/Philadelphia: John Benjamins. https://doi.org/10.1075/tsl.112.01dah

Dahl, Eystein \& Krzysztof Stroński. 2016b. Indo-Aryan ergativity in typological and diachronic perspective (Typological Studies in Language). Amsterdam: John Benjamins Publishing Company. https://doi.org/10.1075/tsl.112 
Delbrück, Berthold. 1893. Grundriss der vergleichenden Grammatik der indogermanischen Sprachen: kurzgefasste Darstellung der Geschichte des Altindischen, Altiranischen (Avestischen u. Altpersischen), Altarmenischen, Altgriechischen, Albanesischen, Lateinischen, Oskisch-Umbrischen, Altirischen, Gotischen, Althochdeutschen, Litauischen und Altkirchenslavischen. Bd 3, Vergleichende Syntax der indogermanischen Sprachen, T. 1. Strassburg: Trübner.

Delbrück, Berthold. 1897. Grundriss der vergleichenden Grammatik der indogermanischen Sprachen: kurzgefasste Darstellung der Geschichte des Altindischen, Altiranischen (Avestischen u. Altpersischen), Altarmenischen, Altgriechischen, Albanesischen, Lateinischen, Oskisch-Umbrischen, Altirischen, Gotischen, Althochdeutschen, Litauischen und Altkirchenslavischen. Bd 4, Vergleichende Syntax der indogermanischen Sprachen, T. 2. Strassburg: Trübner.

Delbrück, Berthold. 1900. Grundriss der vergleichenden Grammatik der indogermanischen Sprachen: kurzgefasste Darstellung der Geschichte des Altindischen, Altiranischen (Avestischen u. Altpersischen), Altarmenischen, Altgriechischen, Albanesischen, Lateinischen, Oskisch-Umbrischen, Altirischen, Gotischen, Althochdeutschen, Litauischen und Altkirchenslavischen. Bd 5, Vergleichende Syntax der indogermanischen Sprachen, T. 3. Strassburg: Trübner. https://doi.org/10.1515/9783111600550

Dench, Alan. 1982. The development of an accusative case marking pattern in the Ngayarda languages of Western Australia. Australian Journal of Linguistics, 2(1). 43-59. https://doi.org/10.1080/07268608208599281

Dixon, R. M.W. 1979. Ergativity. Language 55(1). 59-138. https://doi.org/10.2307/412519

Dixon, R. M.W. 1994. Ergativity. Cambridge: Cambridge University Press. https://doi.org/10.1017/CBO9780511611896

Dixon, R. M.W. 1997. The rise and fall of languages. Cambridge: Cambridge University Press. https://doi.org/10.1017/CBO9780511612060

Dixon, R. M.W. 2010. Basic linguistic theory. Vol. 2, Grammatical topics. Oxford: Oxford University Press.

Drinka, Bridget. 1999. Alignment in Early Proto-Indo-European. In Carol F. Justus \& Edgar C. Polomé (eds.), Language change and typological variation: In honor of Winfred P. Lehmann on the occasion of his 83rd birthday (Journal of Indo-European Studies, Monograph Series, II), 464-500. Washington D.C.: Institute for the Study of Man.

Dryer, Matthew S. \& Martin Haspelmath. 2013. The world atlas of language structures online. Leipzig: Max Planck Institute for Evolutionary Anthropology. http://wals.info

Dunn, Michael. 2014. Language phylogenies. In Claire Bowern \& Bethwyn Evans (eds.), The Routledge handbook of historical linguistics, 190-211. Florence: Routledge.

Felsenstein, Joseph. 1981. Evolutionary trees from DNA sequences: A maximum likelihood approach. Journal of Molecular Evolution 17(6).368-376. https://doi.org/10.1007/BFo1734359

Felsenstein, Joseph. 2004. Inferring phylogenies. Sunderland, Mass.: Sinauer.

Friedrich, Paul. 1975. Proto-Indo-European syntax: The order of meaningful elements (Journal of Indo-European studies. Monograph 4). Washington: Institute for the Study of Man.

Gamkrelidze, Tamaz Valerianovič, Vjačeslav Vsevolodovič Ivanov \& Werner Winter. 1995. Indo-European and the Indo-Europeans: A reconstruction and historical analysis of a proto-language and a proto-culture (Trends in Linguistics. Studies and Monographs 80). Berlin: Mouton de Gruyter. https://doi.org/10.1515/9783110815030

Garrett, Andrew. 1990. The origin of NP split ergativity. Language 66(2). 261-96. https://doi.org/10.2307/414887 
Garrett, Andrew. 1996. Wackernagel's Law and unaccusativity in Hittite. In Aaron Halpern \& Arnold M. Zwicky (eds.), Approaching second. Second position clitics and related phenomena, 85-133. Stanford: CSLI Publications.

Gelman, Andrew \& Donald B. Rubin. 1992. Inference from iterative simulation using multiple sequences. Statistical Science (4). 457-511. https://doi.org/10.1214/ss/1177011136

Goedegebuure, Petra. 2013. Split-ergativity in Hittite. Zeitschrift für Assyriologie und verderasiatische Archäologie 102. 207-303. https://doi.org/10.1515/za-2012-0015

Gray, Russell D. \& Quentin D. Atkinson. 2003. Language-tree divergence times support the Anatolian theory of Indo-European origin. Nature 426 (6965). 435-439. https://doi.org/10.1038/nature02029

Greenberg, Joseph H. 1963. Universals of language: Report of a conference held at Dobbs Ferry, New York, April 13-15, 1961. Cambridge, Mass.: MIT Press.

Greenberg, Joseph H. 1966. Language universals: With special reference to feature hierarchies (Janua linguarum: Series minor 59). The Hague: Mouton.

Greenhill, Simon J., Quentin D. Atkinson, Andrew Meade \& Russell D. Gray. 2010. The shape and tempo of language evolution. Proceedings of the Royal Society: Biological Sciences 277 (1693). https://doi.org/10.1098/rspb.2010.0051

Haiman, John. 1983. Iconic and economic motivation. Language 59(4). 781-819. https://doi.org/10.2307/413373

Harris, Alice C. 2008. Reconstruction in syntax. Reconstruction of patterns. In Gisella Ferraresi \& Maria Goldbach (eds.), Principles of syntactic reconstruction, 73-95. Amsterdam/Philadelphia: John Benjamins. https://doi.org/10.1075/cilt.302.05har

Harris, Alice C. \& Lyle Campbell. 1995. Historical syntax in cross-linguistic perspective (Cambridge studies in linguistics 74). Cambridge: Cambridge University Press. https://doi.org/10.1017/CBO9780511620553

Haspelmath, Martin. 2008. Frequency vs. iconicity in explaining grammatical asymmetries. Cognitive Linguistics 19(1). 1-33. https://doi.org/10.1515/COG.2008.001

Haspelmath, Martin. 2011. On S, A, P, T, and R as comparative concepts for alignment typology. Linguistic Typology 15(3). 535-567. https://doi.org/10.1515/LITY.2011.035

Haspelmath, Martin. 2018. Revisiting the anasynthetic spiral. In Heiko Harrog \& Berndt Heine (eds.), Grammaticalization from a typological perspective, 97-115. Oxford: Oxford University Press. https://doi.org/10.1093/oso/9780198795841.003.0006

Hawkins, John A. 2004. Efficiency and complexity in grammars (Oxford linguistics). Oxford: Oxford University Press. https://doi.org/10.1093/acprof:0so/9780199252695.001.0001

Hendery, Rachel. 2012. Relative clauses in time and space: A case study in the methods of diachronic typology (Typological Studies in Language). Amsterdam: John Benjamins. https://doi.org/10.1075/tsl.101

Hirt, Hermann Alfred. 1934. Indogermanische Grammatik. Cambridge: Cambridge University Press.

Hock, Hans Henrich. 2013. Proto-Indo-European verb-finality reconstruction, typology, validation. Journal of Historical Linguistics 3(1). 49-76. https://doi.org/10.1075/jhl.3.1.04hoc

Hock, Hans Henrich \& Brian D. Joseph. 1996. Language history, language change, and language relationship: An introduction to historical and comparative linguistics (Trends in Linguistics. Studies and Monographs 93). Berlin: Mouton de Gruyter.

Hopper, Paul \& Elizabeth C. Traugott. 2003. Grammaticalization. Cambridge: Cambridge University Press. https://doi.org/10.1017/CBO9781139165525 
Hrozný, Bedřich. 1915. Die Lösung des hethitischen Problems. Mitteilungen der Deutschen Orient-Gesellschaft 56. 17-50.

Huelsenbeck, John P., Rasmus Nielsen \& Jonathan P. Bollback. 2003. Stochastic mapping of morphological characters. Systematic Biology 52(2). 131-158. https://doi.org/10.1080/10635150390192780

Jaeger, Florian T. 2010. Redundancy and reduction: Speakers manage syntactic information density. Cognitive Psychology 61(1). 23-62. https://doi.org/10.1016/j.cogpsych.2010.02.002

Jasanoff, Jay H. 1978. Stative and middle in Indo-European (Innsbrucker Beiträge zur Sprachwissenschaft 23). Innsbruck: Institut für Sprachwissenschaft.

Jasanoff, Jay H. 2003. Hittite and the Indo-European verb (Oxford scholarship online). Oxford: Oxford University Press. https://doi.org/10.1093/acprof:oso/9780199249053.001.0001

Jäger, Gerhard. 2019. Computational historical linguistics. Theoretical Linguistics 45(3/4). 151-182. https://doi.org/10.1515/tl-2019-0011

Klimov, Georgij Andreevich. 1973a. Očerk obščej teorii èrgativnosti. Moskva: Izdatel'stvo Nauka.

Klimov, Georgij Andreevich. 1973b. Tipologija jazykov aktivnogo stroja i rekonstrukcija protoin-doevropejskogo. Izvestija Akademii Nauk SSSR, Serija literatury i jazyka 32. $442-447$.

Klimov, Georgij Andreevich. 1974. On the character of languages of active typology. Linguistics (12), 11-25. https://doi.org/10.1515/ling.1974.12.131.11

Kortlandt, Frederik. 1983. Proto-Indo-European verbal syntax. Journal of Indo-European Studies 11. 307-324.

Krahe, Hans, Hans Schmeja \& Wolfgang Meid. 1972. Grundzüge der vergleichenden Syntax der indogermanischen Sprachen (Innsbrucker Beiträge zur Sprachwissenschaft 8). Innsbruck: Institut für vergleichende Sprachwissenschaft.

Labov, William. 1972. Some principles of linguistic methodology. Language in Society (1). 97-120. https://doi.org/10.1017/So047404500006576

Lehmann, Winfred P. 1973. A structural principle of language and its implications. Language 49(1). 47-66. https://doi.org/10.2307/412102

Lehmann, Winfred P. 1974. Proto-Indo-European syntax. Austin: University of Texas Press.

Lehmann, Winfred P. 1989. Problems of Proto-Indo-European grammar - Residues from PreIndo-European active structure. General Linguistics 29. 228-246.

Lopuhaä-Zwakenberg, Milan. 2019. The Anatolian “ergative”. In Alwin Kloekhorst \& Tijmen Pronk (eds.), The precursors of Proto-Indo-European. The Indo-Anatolian and Indo-Uralic Hypotheses (Leiden Studies in Indo-European), 131-150. Rodopi: Brill. https://doi.org/10.1163/9789004409354_011

Luraghi, Silvia. 2011. The origin of the Proto-Indo-European gender system: Typological considerations. Folia Linguistica 45(2). 435-464. https://doi.org/10.1515/flin.2011.016

Luraghi, Silvia. 2012. Basic valency orientation and the middle voice in Hittite. Studies in Language 36(1). 1-32. https://doi.org/10.1075/sl.36.1.01/ur

Malchukov, Andrej L. 2015. Towards a typology of split ergativity: A TAM-hierarchy for alignment splits. In Ina Bornkessel-Schlesewsky, Andrej Malchukov \& Marc D. Richards (eds.), Scales and hierarchies: A cross-disciplinary perspective, 275-296. Berlin - New York: Mouton de Gruyter. https://doi.org/10.1515/9783110344134.275

Martinet, André. 1962. A functional view of language: Being the Waynflete lectures delivered in the College of St. Mary Magdalen, Oxford 1961. Oxford: Clarendon Press. 
Matasović, Ranko. 2011. Clause alignment in Indo-European. Manuscript. Zagreb: Zagreb University. http://mudrac.ffzg.unizg.hr/ rmatasov/ClauseAlignmentInPIE.pdf.

Matasović, Ranko. 2013. Latin paenitet me, miseret me, pudet me and active clause alignment in Proto-Indo-European. Indogermanische Forschungen (118). 93-110. https://doi.org/10.1515/indo.2013.118.2013.93

Matasović, Ranko. 2004. Gender in Indo-European. Heidelberg: Winter.

Maurits, Luke \& Thomas L. Griffiths. 2014. Tracing the roots of syntax with Bayesian phylogenetics. Proceedings of the National Academy of Sciences 111(37). 13576-13581. https://doi.org/10.1073/pnas.1319042111

McGregor, W. B. 2009. Typology of ergativity. Linguistics and Language Compass 3(1). 480-508. https://doi.org/10.1111/j.1749-818X.2008.00118.x

Meid, Wolfgang. 1975. Probleme der räumlichen und zeitlichen Gliederung des Indogermanischen. In Helmut Rix (ed.), Flexion und Wortbildung, 204-219. Wiesbaden: Ludwig Reichert.

Meier-Brügger, Michael, Matthias Fritz \& Manfred Mayrhofer. 2010. Indogermanische Sprachwissenschaft. Berlin: de Gruyter.

Meiser, Gerhard. 2009. Zur Typologie des urindogermanischen Mediums. In Rosemarie Lühr \& Sabine Ziegler (eds.), Protolanguage and Prehistory. Akten der XII. Fachtagung der Indogermanischen Gesellschaft, vom 11. bis 15. Oktober 2004 in Krakau, 318-334. Wiesbaden: Reichert.

Nichols, Johanna. 1992. Linguistic diversity in space and time. Chicago: University of Chicago Press. https://doi.org/10.7208/chicago/9780226580593.001.0001

Nichols, Johanna. 1995. Diachronically stable structural features. In Henning Andersen (ed.), Historical Linguistics 1993. Selected Papers from the 11th International Conference on Historical Linguistics. Los Angeles 16-20 August 1993, 337-355. Amsterdam - Philadelphia: John Benjamins. https://doi.org/10.1075/cilt.124.27nic

Nichols, Johanna. 1998. The Eurasian spread zone and the Indo-European dispersal. In Roger Blench \& Matthew Spriggs (eds.), Archaeology and language II. Archaeological data and linguistic hypotheses, 220-266. New York: Routledge. https://doi.org/10.4324/9780203202913_chapter_10

Nielsen, Rasmus. 2002. Mapping mutations on phylogenies. Systematic Biology (5). 729-739. https://doi.org/10.1080/10635150290102393

Pooth, Roland, Peter Alexander Kerkhof, Leonid Kulikov \& Jóhanna Barđdal. 2019. The origin of non-canonical case marking of subjects in Proto-Indo-European. Indogermanische Forschungen 124. 245-263. https://doi.org/10.1515/if-2019-0009

Roberts, Ian G. 2007. Diachronic syntax (Oxford textbooks in linguistics 2). Oxford: Oxford University Press.

Ronan, Patricia. 2011. The Celtic languages. In Bernd Kortmann \& Johan van der Auwera (eds.), The languages and linguistics of Europe. A comprehensive guide, 31-46. Berlin/New York: Mouton De Gruyter. https://doi.org/10.1515/9783110220261.31

Rumsey, A. 1987. The chimera of Proto-Indo-European ergativity. Lessons for historical syntax. Lingua 71(1-4). 297-318. https://doi.org/10.1016/0024-3841(87)90076-3

Schlerath, Bernfried. 1981. Ist ein Raum/Zeit-Modell für eine rekonstruierte Sprache möglich?. Zeitschrift für vergleichende Sprachforschung 95(2). 175-202. 
Schmalsteig, William R. 1981. Ergativity in Indo-European. In Yoël L. Arbeitman \& Allan R. Bomhard (eds.), Bono Homini Donum: Essays in Historical Linguistics in Memory of J. Alexander Kerns, 243-258. Amsterdam: John Benjamins. https://doi.org/10.1075/cilt.16.26sch

Schmidt, Karl Horst. 1979. Reconstructing active and ergative stages of Pre-Indo-European. In Frans Plank (ed.), Ergativity: Towards a theory of grammatical relations, 333-345. London: Academic Press.

Silva, Sara Graça da \& Jamshid J. Tehrani. 2016. Comparative phylogenetic analyses uncover the ancient roots of Indo-European folktales. Royal Society Open Science 3(1). https://doi.org/10.1098/rsos.150645

Silverstein, Michael. 1976. Hierarchy of features and ergativity. In R.M.W. Dixon (ed.), Grammatical categories in Australian languages, 112-171. Canberra: Australian National University.

Szemerényi, Oswald. 1989. Einführung in die vergleichende Sprachwissenschaft. Darmstadt: Wissenschaftl. Buchgesellschaft.

Uhlenbeck, C. Cornelis. 1901. Agens und Patiens im Kasussystem der indogermanischen Sprachen. Indogermanische Forschungen 12. 170-171.

Vaillant, A. 1936. L'Ergatif indo-européen. C. Klincksieck.

Walkden, George. 2013. The correspondence problem in syntactic reconstruction. Diachronica, 30(1). 95-122. https://doi.org/10.1075/dia.30.1.04wal

Walkden, George. 2019. The many faces of uniformitarianism in linguistics. Glossa: A Journal of General Linguistics 4(1), 1-17. https://doi.org/10.5334/gjgl.888

Watkins, Calvert. 1976. Towards Proto-Indo-European syntax: Problems and pseudoproblems. In Sanford Steever, Carol A. Walker \& Salikoko S. Mufwene (eds.), Papers from the Parasession on Diachronic Syntax, 305-326. Chicago: Chicago Linguistic Society.

Verbeke, Saartje \& De Cuypere, Ludovic. 2009. The rise of ergativity in Hindi: Assessing the role of grammaticalization. Folia Linguistica Historica (43). 367-389. https://doi.org/10.1515/FLIH.2009.006

Verbeke, Saartje \& De Clercq, Eva. 2016. Looking for ergativity in Indo-Aryan. In Eystein Dahl \& Krzysztof Stronski (eds.), Indo-Aryan ergativity in typological and diachronic perspective, 39-60. Amsterdam/Philadelphia: John Benjamins. https://doi.org/10.1075/tsl.112.02ver

Villar, Francisco. 1984. Ergativity and animate/inanimate gender in Indo-European. Zeitschrift für vergleichende Sprachforschung 97(2). 167-196.

Viti, Carlotta. 2015. Historical syntax: Problems, materials, methods, hypotheses. In Carlotta Viti (ed.), Perspectives on historical syntax, 3-34. Amsterdam/Philadelphia: John Benjamins. https://doi.org/10.1075/slcs.169.01vit

Winter, Werner. 1984. Reconstructional comparative linguistics and the reconstruction of undocumented stages in the development of languages and language families. In Jacek Fisiak (ed.), Historical syntax, 613-625. Berlin/New York: Mouton de Gruyter. https://doi.org/10.1515/9783110824032.613

Witzlack-Makarevich, Alena \& Seržant, Ilja A. 2018. Differential argument marking: Patterns of variation. In Ilja A. Seržant \& Alena Witzlack-Makarevich (eds.), Diachrony of differential argument marking, 1-40. Berlin: Language Science Press.

Yang, Z. 2014. Molecular evolution: A statistical approach. Oxford: Oxford University Press. https://doi.org/10.1093/acprof:0so/9780199602605.001.0001 
Zhou, Kevin \& Claire Bowern. 2015. Quantifying uncertainty in the phylogenetics of Australian numeral systems. Proceedings of the Royal Society B, 282(1815). https://doi.org/10.1098/rspb.2015.1278

\section{Appendices: Data and results}

\section{Appendix 1.}

Languages, including latitude and longitude, used in the current study

\begin{tabular}{|c|c|c|}
\hline Languages & Latitude & Longitude \\
\hline Albanian (Tosk) & 40,44695 & 19,98825 \\
\hline Angloromani & 53,77952 & $-2,35527$ \\
\hline Ashkun & 35,25591 & 70,79106 \\
\hline Assamese & 26,14354 & 91,79022 \\
\hline Avestan & 31,70708 & 55,9499 \\
\hline Baluchi & 26,27794 & 65,03622 \\
\hline Bengali & 23,78057 & 90,27924 \\
\hline Breton & 47,99562 & $-4,10286$ \\
\hline Bulgarian & 42,69859 & 23,3535 \\
\hline Catalan & 41,37923 & 2,179642 \\
\hline Classical Greek & 37,69686 & 23,99921 \\
\hline Cornish & 50,19182 & $-5,56752$ \\
\hline Croatian & 45,81349 & 15,99266 \\
\hline Czech & 50,07124 & 14,46814 \\
\hline Danish & 55,67989 & 12,58318 \\
\hline Dutch & 52,37437 & 4,898126 \\
\hline Elfdalian & 61,22594 & 14,04049 \\
\hline English & 51,49773 & $-0,10006$ \\
\hline Faroese & 62,00975 & $-6,77332$ \\
\hline French & 48,85445 & 2,347857 \\
\hline Frisian & 53,20394 & 5,795597 \\
\hline Friulian & 46,12703 & 13,485 \\
\hline German & 52,52082 & 13,40909 \\
\hline Gilaki & 37,52606 & 49,284 \\
\hline Gothic & 53,04287 & 20,19932 \\
\hline Gujarati & 22,44456 & 72,13987 \\
\hline
\end{tabular}




\begin{tabular}{|c|c|c|}
\hline Languages & Latitude & Longitude \\
\hline Hindi & 28,62525 & 77,225 \\
\hline Hittite & 40,01395 & 34,62116 \\
\hline Icelandic & 64,14424 & $-21,9397$ \\
\hline Irish & 53,24443 & $-9,3011$ \\
\hline Italian & 43,11596 & 12,38515 \\
\hline Kashmiri & 34,323 & 75,93918 \\
\hline Kati & 35,79999 & 71,31457 \\
\hline Khowar & 36,45796 & 72,51658 \\
\hline Konkani & 19,26208 & 72,87107 \\
\hline Kurdish (Kurmanji) & 37,78808 & 43,82275 \\
\hline Kurdish (Sorani) & 35,82116 & 45,72851 \\
\hline Ladin & 46,65738 & 11,92376 \\
\hline Latin & 41,89019 & 12,4923 \\
\hline Latvian & 56,915 & 24,11327 \\
\hline Lithuanian & 54,68018 & 25,25585 \\
\hline Low German & 53,93199 & 9,488653 \\
\hline Luwian & 36,6206 & 36,78827 \\
\hline Maithili & 26,0754 & 86,15545 \\
\hline Maldivian & 4,17191 & 73,51194 \\
\hline Manx & 54,15199 & $-4,48466$ \\
\hline Marathi & 19,38701 & 75,49471 \\
\hline Middle Breton & 47,20785 & $-1,53247$ \\
\hline Middle Dutch & 52,21307 & 5,959192 \\
\hline Middle English & 51,31361 & $-0,75862$ \\
\hline Middle Greek & 41,05864 & 28,99756 \\
\hline Middle High German & 48,74272 & 9,717403 \\
\hline Middle Irish & 52,65892 & $-8,63441$ \\
\hline Middle Low German & 53,86778 & 10,68504 \\
\hline Middle Persian & 32,64703 & 51,67588 \\
\hline Middle Welsh & 52,24036 & $-3,38002$ \\
\hline Modern Armenian & 40,14739 & 44,52716 \\
\hline Modern Greek & 38,02862 & 23,69433 \\
\hline Nepali & 26,6597 & 89,24363 \\
\hline Norwegian (Bokmål) & 59,91279 & 10,7408 \\
\hline Norwegian (Nynorsk) & 60,33098 & 5,075361 \\
\hline
\end{tabular}




\begin{tabular}{|c|c|c|}
\hline Languages & Latitude & Longitude \\
\hline Old Church Slavonic & 43,95597 & 22,87177 \\
\hline Old Dutch & 52,09095 & 5,123259 \\
\hline Old English & 51,0607 & $-1,31416$ \\
\hline Old French & 48,85445 & 2,347857 \\
\hline Old Frisian & 53,2157 & 6,567738 \\
\hline Old High German & 49,79548 & 9,962616 \\
\hline Old Irish & 53,72679 & $-6,87383$ \\
\hline Old Italian & 43,77628 & 11,24925 \\
\hline Old Norse & 63,42698 & 10,39752 \\
\hline Old Persian & 29,9355 & 52,8912 \\
\hline Old Portuguese & 41,15818 & $-8,62914$ \\
\hline Old Provençal & 43,42683 & 6,222519 \\
\hline Old Prussian & 54,43629 & 19,9008 \\
\hline Old Russian & 58,52143 & 31,27535 \\
\hline Old Saxon & 53,07585 & 8,806043 \\
\hline Old Spanish & 42,386 & $-3,894$ \\
\hline Old Swedish & 58,48108 & 16,32194 \\
\hline Oriya & 20,60855 & 86,27841 \\
\hline Ossetian (Iron) & 43,0438 & 44,67569 \\
\hline Pali & 27,6179 & 83,00038 \\
\hline Parachi & 34,83289 & 69,7026 \\
\hline Pashto & 31,43293 & 68,1888 \\
\hline Persian & 32,73531 & 55,74804 \\
\hline Polish & 52,23789 & 20,99402 \\
\hline Portuguese & 38,70804 & $-9,13513$ \\
\hline Prakrit & 25,3791 & 84,72798 \\
\hline Prasun & 35,33661 & 70,74162 \\
\hline Provençal & 43,42683 & 6,222519 \\
\hline Punjabi & 31,5366 & 74,34941 \\
\hline Romani (Arli) & 42,97035 & 19,88117 \\
\hline Romani (Burgenland) & 47,19316 & 16,37753 \\
\hline Romani (Kale) & 60,97209 & 21,47097 \\
\hline Romani (Kelderash) & 47,18768 & 22,49509 \\
\hline Romani (Lovara) & 47,40154 & 23,0902 \\
\hline Romani (Sepečides) & 38,3928 & 27,13167 \\
\hline
\end{tabular}




\begin{tabular}{|c|c|c|}
\hline Languages & Latitude & Longitude \\
\hline Romani (Sinte) & 51,4992 & 10,20342 \\
\hline Romanian & 44,42751 & 26,08637 \\
\hline Romansh & 46,49676 & 9,838341 \\
\hline Russian & 55,67758 & 37,64843 \\
\hline Sanskrit & 23,51142 & 76,28612 \\
\hline Sardinian & 40,31746 & 9,32737 \\
\hline Scandoromani & 59,48131 & 13,15862 \\
\hline Scottish Gaelic & 57,16276 & $-7,36897$ \\
\hline Serbian & 44,80133 & 20,47216 \\
\hline Shughni & 38,38964 & 71,50304 \\
\hline Sicilian & 38,11514 & 13,36835 \\
\hline Sindhi & 23,25348 & 69,6748 \\
\hline Sinhalese & 6,935115 & 79,85635 \\
\hline Slovene & 46,05059 & 14,50823 \\
\hline Sogdian & 39,64658 & 66,96268 \\
\hline Spanish & 40,41688 & $-3,70348$ \\
\hline Swedish & 59,73823 & 17,43872 \\
\hline Swiss German & 47,36888 & 8,538354 \\
\hline Tajik & 38,66346 & 70,34262 \\
\hline Talysh & 38,85417 & 48,73002 \\
\hline Tocharian A & 41,76034 & 86,15479 \\
\hline Tocharian B & 41,6455 & 81,51444 \\
\hline Ukrainian & 50,44947 & 30,52541 \\
\hline Upper Sorbian & 51,17991 & 14,42544 \\
\hline Urdu & 33,68114 & 73,01842 \\
\hline Wakhi & 37,21948 & 72,76006 \\
\hline Walloon & 50,46448 & 4,865382 \\
\hline Welsh & 52,92641 & $-4,38518$ \\
\hline Yiddish & 49,85303 & 24,03117 \\
\hline
\end{tabular}




\section{Appendix 2.}

List of typological features for alignment (extracted from DiACL database, https://diacl.ht.lu .se/) used in current study. Grid = topmost organizational unit in database, corresponding to linguistic domain, Feature $=$ second organizational unit in database, Feature description = Description of Feature in database, Variant = lowest organizational unit in database, Variant description = description of variant in database, ID = unique database ID of Variant.

\begin{tabular}{|c|c|c|c|c|c|}
\hline Grid & Feature & $\begin{array}{l}\text { Feature } \\
\text { description }\end{array}$ & Variant & Variant description & ID \\
\hline Alignment & $\begin{array}{l}\text { Noun: } \\
\text { Simple } \\
\text { Past }\end{array}$ & $\begin{array}{l}\text { In simple } \\
\text { past: how is } \\
\text { the } \\
\text { marking of } \\
\text { subject and } \\
\text { object of } \\
\text { nouns } \\
\text { realized? }\end{array}$ & $\mathrm{N}: \mathrm{PST}: \mathrm{A}=\mathrm{O} ?$ & $\begin{array}{l}\text { In simple past: Is } \\
\text { the noun form for A } \\
\text { the same as for O? } \\
\text { Ie: Does the noun } \\
\text { look the same when } \\
\text { it is subject of a } \\
\text { transitive clause } \\
\text { than when it is } \\
\text { object of a transitive } \\
\text { clause? }\end{array}$ & 302 \\
\hline Alignment & $\begin{array}{l}\text { Noun: } \\
\text { Simple } \\
\text { Past }\end{array}$ & $\begin{array}{l}\text { In simple } \\
\text { past: how is } \\
\text { the } \\
\text { marking of } \\
\text { subject and } \\
\text { object of } \\
\text { nouns } \\
\text { realized? }\end{array}$ & $\mathrm{N}: \mathrm{PST}: \mathrm{A}=\mathrm{Sa} ?$ & $\begin{array}{l}\text { In simple past:Is the } \\
\text { noun form for A the } \\
\text { same as for Sa? Ie: } \\
\text { Does the noun look } \\
\text { the same when it is } \\
\text { subject of a } \\
\text { transitive clause as } \\
\text { when it is subject of } \\
\text { an agentive } \\
\text { intransitive verb } \\
\text { such as "work" or } \\
\text { "dance"? }\end{array}$ & 303 \\
\hline Alignment & $\begin{array}{l}\text { Noun: } \\
\text { Simple } \\
\text { Past }\end{array}$ & $\begin{array}{l}\text { In simple } \\
\text { past: how is } \\
\text { the } \\
\text { marking of } \\
\text { subject and } \\
\text { object of } \\
\text { nouns } \\
\text { realized? }\end{array}$ & $\mathrm{N}: \mathrm{PST}: \mathrm{O}=\mathrm{So} ?$ & $\begin{array}{l}\text { In simple past: Is } \\
\text { the noun form for } \\
\text { O the same as for } \\
\text { So? Ie: Does the } \\
\text { noun look the same } \\
\text { when it is object of } \\
\text { a transitive clause as } \\
\text { when it is subject of } \\
\text { an unaccusative }\end{array}$ & 304 \\
\hline
\end{tabular}




\begin{tabular}{|c|c|c|c|c|c|}
\hline Grid & Feature & $\begin{array}{l}\text { Feature } \\
\text { description }\end{array}$ & Variant & Variant description & ID \\
\hline & & & & $\begin{array}{l}\text { verb such as "fall" } \\
\text { or "die"? }\end{array}$ & \\
\hline Alignment & $\begin{array}{l}\text { Noun: } \\
\text { Simple } \\
\text { Past }\end{array}$ & $\begin{array}{l}\text { In simple } \\
\text { past: how is } \\
\text { the } \\
\text { marking of } \\
\text { subject and } \\
\text { object of } \\
\text { nouns } \\
\text { realized? }\end{array}$ & $\mathrm{N}: \mathrm{PST}: \mathrm{Sa}=\mathrm{So} ?$ & $\begin{array}{l}\text { In simple past: } \\
\text { Does a noun bear } \\
\text { the same case form } \\
\text { when it is Sa } \\
\text { (subject of e.g. } \\
\text { work) or So } \\
\text { (subject of e.g. fall } \\
\text { or die)? Ie: There } \\
\text { does not exist a split } \\
\text { into stative and } \\
\text { active intransitive } \\
\text { verbs. }\end{array}$ & 305 \\
\hline Alignment & $\begin{array}{l}\text { Noun: } \\
\text { Present } \\
\text { Progressive }\end{array}$ & $\begin{array}{l}\text { In present } \\
\text { progressive: } \\
\text { how is the } \\
\text { marking of } \\
\text { subject and } \\
\text { object of } \\
\text { nouns } \\
\text { realized? }\end{array}$ & $\mathrm{N}: \mathrm{PROG}: \mathrm{A}=\mathrm{O} ?$ & $\begin{array}{l}\text { In present } \\
\text { progressive: Is the } \\
\text { noun form for A the } \\
\text { same as for O? I.e.: } \\
\text { Does the noun look } \\
\text { the same when it is } \\
\text { subject of a } \\
\text { transitive clause and } \\
\text { when it is object of } \\
\text { a transitive clause? }\end{array}$ & 306 \\
\hline Alignment & $\begin{array}{l}\text { Noun: } \\
\text { Present } \\
\text { Progressive }\end{array}$ & $\begin{array}{l}\text { In present } \\
\text { progressive: } \\
\text { how is the } \\
\text { marking of } \\
\text { subject and } \\
\text { object of } \\
\text { nouns } \\
\text { realized? }\end{array}$ & $\mathrm{N}: \mathrm{PROG}: \mathrm{A}=\mathrm{Sa}$ ? & $\begin{array}{l}\text { In present } \\
\text { progressive:Is the } \\
\text { noun form for A the } \\
\text { same as for Sa? I.e.: } \\
\text { Does the noun look } \\
\text { the same when it is } \\
\text { subject of a } \\
\text { transitive clause and } \\
\text { when it is subject of } \\
\text { an agentive } \\
\text { intransitive verb } \\
\text { such as "work" or } \\
\text { "dance"? }\end{array}$ & 307 \\
\hline
\end{tabular}




\begin{tabular}{|c|c|c|c|c|c|}
\hline Grid & Feature & $\begin{array}{l}\text { Feature } \\
\text { description }\end{array}$ & Variant & Variant description & ID \\
\hline Alignment & $\begin{array}{l}\text { Noun: } \\
\text { Present } \\
\text { Progressive }\end{array}$ & $\begin{array}{l}\text { In present } \\
\text { progressive: } \\
\text { how is the } \\
\text { marking of } \\
\text { subject and } \\
\text { object of } \\
\text { nouns } \\
\text { realized? }\end{array}$ & $\mathrm{N}: \mathrm{PROG}: \mathrm{O}=\mathrm{So} ?$ & $\begin{array}{l}\text { In present } \\
\text { progressive: Is the } \\
\text { noun form for O } \\
\text { the same as for So? } \\
\text { I.e.: Does the noun } \\
\text { look the same when } \\
\text { it is object of a } \\
\text { transitive clause and } \\
\text { when it is subject of } \\
\text { an unaccusative } \\
\text { verb such as "fall" } \\
\text { or "die"? }\end{array}$ & 308 \\
\hline Alignment & $\begin{array}{l}\text { Noun: } \\
\text { Present } \\
\text { Progressive }\end{array}$ & $\begin{array}{l}\text { In present } \\
\text { progressive: } \\
\text { how is the } \\
\text { marking of } \\
\text { subject and } \\
\text { object of } \\
\text { nouns } \\
\text { realized? }\end{array}$ & $\mathrm{N}: \mathrm{PROG}: \mathrm{Sa}=\mathrm{So} ?$ & $\begin{array}{l}\text { In present } \\
\text { progressive: does a } \\
\text { noun bear the same } \\
\text { case form when it is } \\
\text { Sa (subject of e.g., } \\
\text { "work") or So } \\
\text { (subject of e.g., } \\
\text { "fall" or "die")? I.e.: } \\
\text { The language does } \\
\text { not have a split } \\
\text { between stative and } \\
\text { active intransitive } \\
\text { verbs. }\end{array}$ & 309 \\
\hline Alignment & $\begin{array}{l}\text { Pronoun: } \\
\text { Simple } \\
\text { Past }\end{array}$ & $\begin{array}{l}\text { In present } \\
\text { progressive: } \\
\text { how is the } \\
\text { marking of } \\
\text { subject and } \\
\text { object of } \\
\text { pronouns } \\
\text { realized? }\end{array}$ & $\mathrm{P}: \mathrm{PST}: \mathrm{A}=\mathrm{O} ?$ & $\begin{array}{l}\text { In simple past: Is } \\
\text { the pronoun form } \\
\text { for A the same as } \\
\text { for O? I.e.: Does the } \\
\text { pronoun look the } \\
\text { same when it is } \\
\text { subject of a } \\
\text { transitive clause } \\
\text { than when it is } \\
\text { object of a transitive } \\
\text { clause? }\end{array}$ & 310 \\
\hline
\end{tabular}




\begin{tabular}{|c|c|c|c|c|c|}
\hline Grid & Feature & $\begin{array}{l}\text { Feature } \\
\text { description }\end{array}$ & Variant & Variant description & ID \\
\hline Alignment & $\begin{array}{l}\text { Pronoun: } \\
\text { Simple } \\
\text { Past }\end{array}$ & $\begin{array}{l}\text { In present } \\
\text { progressive: } \\
\text { how is the } \\
\text { marking of } \\
\text { subject and } \\
\text { object of } \\
\text { pronouns } \\
\text { realized? }\end{array}$ & $\mathrm{P}: \mathrm{PST}: \mathrm{A}=\mathrm{Sa} ?$ & $\begin{array}{l}\text { In simple past: Is } \\
\text { the pronoun form } \\
\text { for A the same as } \\
\text { for Sa? I.e.: Does } \\
\text { the pronoun look } \\
\text { the same when it is } \\
\text { subject of a } \\
\text { transitive clause } \\
\text { than when it is } \\
\text { subject of an } \\
\text { agentive intransitive } \\
\text { verb such as "work" } \\
\text { or "dance"? }\end{array}$ & 311 \\
\hline Alignment & $\begin{array}{l}\text { Pronoun: } \\
\text { Simple } \\
\text { Past }\end{array}$ & $\begin{array}{l}\text { In present } \\
\text { progressive: } \\
\text { how is the } \\
\text { marking of } \\
\text { subject and } \\
\text { object of } \\
\text { pronouns } \\
\text { realized? }\end{array}$ & P:PST: $\mathrm{O}=$ So? & $\begin{array}{l}\text { In simple past: Is } \\
\text { the pronoun form } \\
\text { for O the same as } \\
\text { for So? I.e.: Does } \\
\text { the pronoun look } \\
\text { the same when it is } \\
\text { object of a transitive } \\
\text { clause than when it } \\
\text { is subject of an } \\
\text { unaccusative verb } \\
\text { such as "fall" or } \\
\text { "die"? }\end{array}$ & 312 \\
\hline Alignment & $\begin{array}{l}\text { Pronoun: } \\
\text { Simple } \\
\text { Past }\end{array}$ & $\begin{array}{l}\text { In present } \\
\text { progressive: } \\
\text { how is the } \\
\text { marking of } \\
\text { subject and } \\
\text { object of } \\
\text { pronouns } \\
\text { realized? }\end{array}$ & $\mathrm{P}: \mathrm{PST}: \mathrm{Sa}=\mathrm{So} ?$ & $\begin{array}{l}\text { In simple past: } \\
\text { Does the pronoun } \\
\text { bear the same case } \\
\text { form when it is Sa } \\
\text { (subject of e.g. } \\
\text { work) or So } \\
\text { (subject of e.g. fall } \\
\text { or die)? I.e.: There } \\
\text { does not exist a split } \\
\text { into stative and } \\
\text { active intransitive } \\
\text { verbs. }\end{array}$ & 313 \\
\hline
\end{tabular}




\begin{tabular}{|c|c|c|c|c|c|}
\hline Grid & Feature & $\begin{array}{l}\text { Feature } \\
\text { description }\end{array}$ & Variant & Variant description & ID \\
\hline Alignment & $\begin{array}{l}\text { Pronoun: } \\
\text { Present } \\
\text { Progressive }\end{array}$ & $\begin{array}{l}\text { In present } \\
\text { progressive: } \\
\text { how is the } \\
\text { marking of } \\
\text { subject and } \\
\text { object of } \\
\text { pronouns } \\
\text { realized? }\end{array}$ & P:PROG:A=O? & $\begin{array}{l}\text { In present } \\
\text { progressive: Is the } \\
\text { pronoun form for A } \\
\text { the same as for O? } \\
\text { I.e.: Does the } \\
\text { pronoun look the } \\
\text { same when it is } \\
\text { subject of a } \\
\text { transitive clause } \\
\text { than when it is } \\
\text { object of a transitive } \\
\text { clause? }\end{array}$ & 314 \\
\hline Alignment & $\begin{array}{l}\text { Pronoun: } \\
\text { Present } \\
\text { Progressive }\end{array}$ & $\begin{array}{l}\text { In present } \\
\text { progressive: } \\
\text { how is the } \\
\text { marking of } \\
\text { subject and } \\
\text { object of } \\
\text { pronouns } \\
\text { realized? }\end{array}$ & P:PROG:A=Sa? & $\begin{array}{l}\text { In present } \\
\text { progressive:Is the } \\
\text { pronoun form for A } \\
\text { the same as for Sa? } \\
\text { I.e.: Does the } \\
\text { pronoun look the } \\
\text { same when it is } \\
\text { subject of a } \\
\text { transitive clause as } \\
\text { when it is subject of } \\
\text { an agentive } \\
\text { intransitive verb } \\
\text { such as "work" or } \\
\text { "dance"? }\end{array}$ & 315 \\
\hline Alignment & $\begin{array}{l}\text { Pronoun: } \\
\text { Present } \\
\text { Progressive }\end{array}$ & $\begin{array}{l}\text { In present } \\
\text { progressive: } \\
\text { how is the } \\
\text { marking of } \\
\text { subject and } \\
\text { object of } \\
\text { pronouns } \\
\text { realized? }\end{array}$ & P:PROG: $\mathrm{O}=\mathrm{So} ?$ & $\begin{array}{l}\text { In present } \\
\text { progressive: Is the } \\
\text { pronoun form for O } \\
\text { the same as for So? } \\
\text { I.e.: Does the } \\
\text { pronoun look the } \\
\text { same when it is } \\
\text { object of a transitive } \\
\text { clause than when it } \\
\text { is subject of an } \\
\text { unaccusative verb }\end{array}$ & 316 \\
\hline
\end{tabular}




\begin{tabular}{|c|c|c|c|c|c|}
\hline Grid & Feature & $\begin{array}{l}\text { Feature } \\
\text { description }\end{array}$ & Variant & Variant description & ID \\
\hline & & & & $\begin{array}{l}\text { such as "die" or } \\
\text { "fall"? }\end{array}$ & \\
\hline Alignment & $\begin{array}{l}\text { Pronoun: } \\
\text { Present } \\
\text { Progressive }\end{array}$ & $\begin{array}{l}\text { In present } \\
\text { progressive: } \\
\text { how is the } \\
\text { marking of } \\
\text { subject and } \\
\text { object of } \\
\text { pronouns } \\
\text { realized? }\end{array}$ & 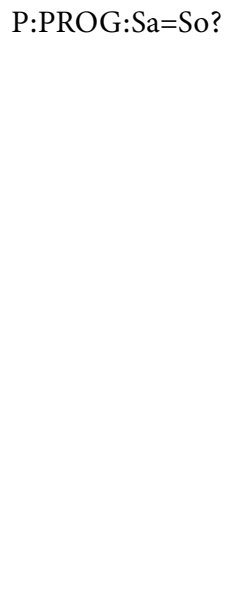 & $\begin{array}{l}\text { In present } \\
\text { progressive: Does a } \\
\text { pronoun bear the } \\
\text { same case form } \\
\text { when it is Sa } \\
\text { (subject of e.g. } \\
\text { work) or So } \\
\text { (subject of e.g. fall } \\
\text { or die)? Ie: There } \\
\text { does not exist a split } \\
\text { into stative and } \\
\text { active intransitive } \\
\text { verbs. }\end{array}$ & 317 \\
\hline Alignment & $\begin{array}{l}\text { Verb: } \\
\text { Simple } \\
\text { Past }\end{array}$ & $\begin{array}{l}\text { In simple } \\
\text { past, how is } \\
\text { alignment } \\
\text { realized on } \\
\text { the verb? }\end{array}$ & $\mathrm{V}: \mathrm{PST}: \mathrm{A}=\mathrm{O} ?$ & $\begin{array}{l}\text { In simple past: Is } \\
\text { the verb affix for A } \\
\text { the same as for O? } \\
\text { I.e.: Does the verb } \\
\text { look the same when } \\
\text { it refers to the } \\
\text { subject of a } \\
\text { transitive clause } \\
\text { than when it refers } \\
\text { to the object of a } \\
\text { transitive clause? If } \\
\text { there is no O- } \\
\text { marking on the } \\
\text { verb, but there is an } \\
\text { S-marking, the } \\
\text { answer would be } \\
\text { no, they do not look } \\
\text { the same. (e.g., } \\
\text { German, Russian) If } \\
\text { there is neither an } \\
\text { O, nor an A } \\
\text { marking, like in } \\
\text { Swedish, the answer }\end{array}$ & 318 \\
\hline
\end{tabular}




\begin{tabular}{|c|c|c|c|c|c|}
\hline Grid & Feature & $\begin{array}{l}\text { Feature } \\
\text { description }\end{array}$ & Variant & Variant description & ID \\
\hline & & & & would be yes, they & \\
\hline & & & & look the same! & \\
\hline \multirow[t]{12}{*}{ Alignment } & Verb: & In simple & $\mathrm{V}: \mathrm{PST}: \mathrm{A}=\mathrm{Sa} ?$ & In simple past: Is & 319 \\
\hline & Simple & past, how is & & the verb affix for $A$ & \\
\hline & Past & alignment & & the same as for $\mathrm{Sa}$ ? & \\
\hline & & realized on & & I.e.: Does the verb & \\
\hline & & the verb? & & look the same when & \\
\hline & & & & it refers to subject of & \\
\hline & & & & a transitive clause & \\
\hline & & & & than when it refers & \\
\hline & & & & to subject of an & \\
\hline & & & & agentive intransitive & \\
\hline & & & & verb like "work" or & \\
\hline & & & & "dance"? & \\
\hline \multirow[t]{12}{*}{ Alignment } & Verb: & In simple & $\mathrm{V}: \mathrm{PST}: \mathrm{O}=\mathrm{So} ?$ & In simple past: Is & 320 \\
\hline & Simple & past, how is & & the verb affix for $\mathrm{O}$ & \\
\hline & Past & alignment & & the same as for So? & \\
\hline & & realized on & & I.e.: Does the verb & \\
\hline & & the verb? & & look the same when & \\
\hline & & & & it refers to the & \\
\hline & & & & object of a transitive & \\
\hline & & & & clause as when it & \\
\hline & & & & refers to the subject & \\
\hline & & & & of an unaccusative & \\
\hline & & & & verb (such as "fall" & \\
\hline & & & & or "die")? & \\
\hline \multirow[t]{12}{*}{ Alignment } & Verb: & In simple & $\mathrm{V}: \mathrm{PST}: \mathrm{Sa}=\mathrm{So} ?$ & In simple past: Is & 321 \\
\hline & Simple & past, how is & & the verb affix the & \\
\hline & Past & alignment & & same for Sa (subject & \\
\hline & & realized on & & of e.g. work) as or & \\
\hline & & the verb? & & So (subject of e.g. & \\
\hline & & & & fall or die)? I.e., & \\
\hline & & & & does the verb & \\
\hline & & & & agreement affix look & \\
\hline & & & & the same regardless & \\
\hline & & & & of whether the verb & \\
\hline & & & & is "work" or "die" & \\
\hline & & & & (as in German: & \\
\hline
\end{tabular}




\begin{tabular}{|c|c|c|c|c|c|}
\hline Grid & Feature & $\begin{array}{l}\text { Feature } \\
\text { description }\end{array}$ & Variant & Variant description & ID \\
\hline & & & & $\begin{array}{l}\text { "arbeitete-st", } \\
\text { "starb-st"). I.e.: } \\
\text { There does not exist } \\
\text { a split into } \\
\text { unaccusative and } \\
\text { agentive intransitive } \\
\text { verbs. }\end{array}$ & \\
\hline Alignment & $\begin{array}{l}\text { Verb: } \\
\text { Present } \\
\text { Progressive }\end{array}$ & $\begin{array}{l}\text { In present } \\
\text { progressive, } \\
\text { how is } \\
\text { alignment } \\
\text { realized on } \\
\text { the verb? }\end{array}$ & $\mathrm{V}: \mathrm{PROG}: \mathrm{A}=\mathrm{O} ?$ & $\begin{array}{l}\text { In present } \\
\text { progressive: Is the } \\
\text { verb affix for A the } \\
\text { same as for O? Ie: } \\
\text { Does the verb look } \\
\text { the same when it } \\
\text { refers to the subject } \\
\text { of a transitive clause } \\
\text { than when it refers } \\
\text { to the object of a } \\
\text { transitive clause? If } \\
\text { there is no O- } \\
\text { marking on the } \\
\text { verb, but there is an } \\
\text { S-marking, the } \\
\text { answer would be } \\
\text { no, they do not look } \\
\text { the same. (e.g. } \\
\text { German, Russian) If } \\
\text { there is neither an } \\
\text { O, nor an A } \\
\text { marking like in } \\
\text { Swedish, the answer } \\
\text { would be yes, they } \\
\text { look the same! }\end{array}$ & 322 \\
\hline Alignment & $\begin{array}{l}\text { Verb: } \\
\text { Present } \\
\text { Progressive }\end{array}$ & $\begin{array}{l}\text { In present } \\
\text { progressive, } \\
\text { how is } \\
\text { alignment } \\
\text { realized on } \\
\text { the verb? }\end{array}$ & $\mathrm{V}: \mathrm{PROG}: \mathrm{A}=\mathrm{Sa} ?$ & $\begin{array}{l}\text { In present } \\
\text { progressive:Is the } \\
\text { verb affix for A the } \\
\text { same as for Sa? Ie: } \\
\text { Does the verb look } \\
\text { the same when it }\end{array}$ & 323 \\
\hline
\end{tabular}




\begin{tabular}{|c|c|c|c|c|c|}
\hline Grid & Feature & $\begin{array}{l}\text { Feature } \\
\text { description }\end{array}$ & Variant & Variant description & ID \\
\hline & & & & $\begin{array}{l}\text { refers to subject of a } \\
\text { transitive clause as } \\
\text { when it refers to } \\
\text { subject of an } \\
\text { agentive intransitive } \\
\text { verb such as } \\
\text { "work"? }\end{array}$ & \\
\hline Alignment & $\begin{array}{l}\text { Verb: } \\
\text { Present } \\
\text { Progressive }\end{array}$ & $\begin{array}{l}\text { In present } \\
\text { progressive, } \\
\text { how is } \\
\text { alignment } \\
\text { realized on } \\
\text { the verb? }\end{array}$ & V:PROG: $\mathrm{O}=$ So? & $\begin{array}{l}\text { In present } \\
\text { progressive: Is the } \\
\text { verb affix the same } \\
\text { for O as for So? Ie: } \\
\text { Does the verb look } \\
\text { the same when it } \\
\text { refers to the object } \\
\text { of a transitive clause } \\
\text { as when it refers to } \\
\text { the subject of an } \\
\text { unaccusative verb } \\
\text { (such as "fall" or } \\
\text { "die")? }\end{array}$ & 324 \\
\hline Alignment & $\begin{array}{l}\text { Verb: } \\
\text { Present } \\
\text { Progressive }\end{array}$ & $\begin{array}{l}\text { In present } \\
\text { progressive, } \\
\text { how is } \\
\text { alignment } \\
\text { realized on } \\
\text { the verb? }\end{array}$ & $\mathrm{V}: \mathrm{PROG}: \mathrm{Sa}=\mathrm{So} ?$ & $\begin{array}{l}\text { In present } \\
\text { progressive: Is the } \\
\text { verb affix the same } \\
\text { for Sa (subject of } \\
\text { e.g. "work") as or } \\
\text { So (subject of e.g. } \\
\text { "fall" or "die")? I.e. } \\
\text { does the verb } \\
\text { agreement affix look } \\
\text { the same regardless } \\
\text { of whether the verb } \\
\text { is "work" or "die" } \\
\text { (as in German: } \\
\text { arbeite-t, stirb-t). } \\
\text { I.e.: There does not } \\
\text { exist a split into } \\
\text { unaccusative and }\end{array}$ & 325 \\
\hline
\end{tabular}




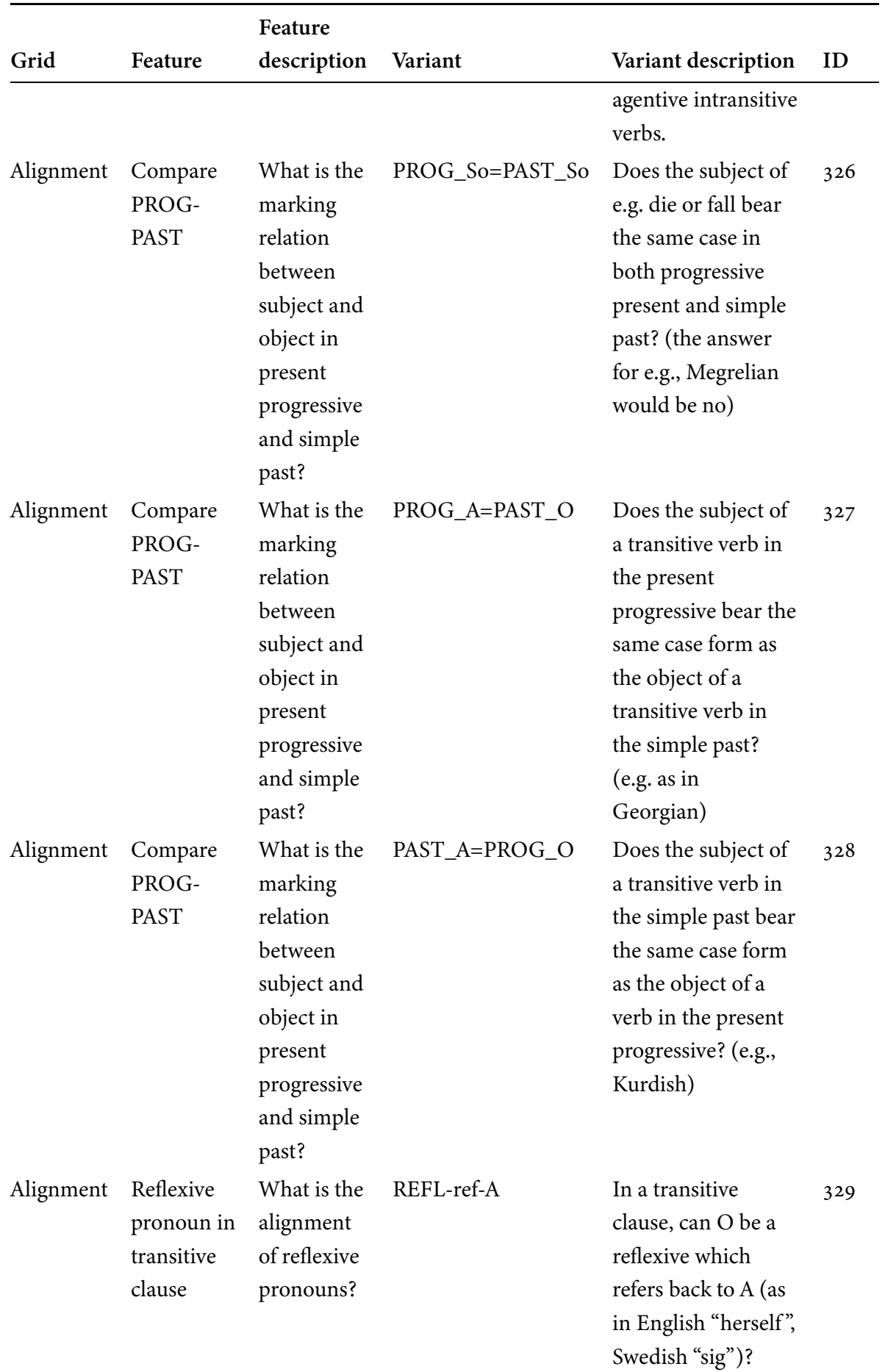




\begin{tabular}{llllll}
\hline Grid & Feature & $\begin{array}{l}\text { Feature } \\
\text { description }\end{array}$ & Variant & Variant description & ID \\
\hline Alignment & $\begin{array}{l}\text { Reflexive } \\
\text { pronoun in } \\
\text { transitive }\end{array}$ & $\begin{array}{l}\text { What is the } \\
\text { alignment } \\
\text { clause }\end{array}$ & REFL-ref-O & $\begin{array}{l}\text { In a transitive } \\
\text { clause, can A be a }\end{array}$ & 330 \\
& pronouns? & $\begin{array}{l}\text { reflexive which } \\
\text { refers back to O (as }\end{array}$ & \\
& & appears to be the & \\
& & case in some & \\
& & Caucasian & \\
& & languages)? & \\
\end{tabular}

\section{Appendix 3.}

Multistate characters and reconstructed probabilities of traits at the probability of presence at the root of the tree. Block = ID of multistate character block (for reference in text), Label = descriptive property label, ID = unique trait ID ( $\mathrm{A}=$ alignment, $\mathrm{NM}=$ nominal morphology, $\mathrm{T}=$ tense, $\mathrm{VM}=$ verbal morphology, $\mathrm{WO}=$ word order), Variant (1-4) = Variant of multistate character from DiACL, given as Grid|Feature|Variant (see S2a), Result = reconstructed probability of presence for earhc trait at the protolanguage state.

\begin{tabular}{|c|c|c|c|c|c|c|c|}
\hline Block & Label & ID & Variant (1) & Variant (2) & Variant (3) & Variant (4) & Result \\
\hline \multirow[t]{5}{*}{1} & Present-Past & & $\begin{array}{l}\text { ALIGNMENT| } \\
\text { Compare PROG- } \\
\text { PAST|PAST_A= } \\
\text { PROG_O }\end{array}$ & $\begin{array}{l}\text { ALIGNMENT| } \\
\text { Compare } \\
\text { PROG- } \\
\text { PAST|PROG_A= } \\
\text { PST_O }\end{array}$ & $\begin{array}{l}\text { ALIGNMENT| } \\
\text { Compare PROG- } \\
\text { PAST|PROG_So= } \\
\text { PST_So }\end{array}$ & & \\
\hline & $\begin{array}{l}\text { Present-Past: No } \\
\text { marking difference }\end{array}$ & $\mathrm{A}_{1}$ & 0 & o & o & & 0.034475 \\
\hline & $\begin{array}{l}\text { Present-Past: A } \\
\text { marking in Present } \\
\text { Progressive and Past }\end{array}$ & $\mathrm{A} 2$ & 0 & o & 1 & & 0.765625 \\
\hline & $\begin{array}{l}\text { Present-Past: Active- } \\
\text { ergative in Present } \\
\text { Prog and Past }\end{array}$ & $\mathrm{A}_{3}$ & 0 & 1 & 1 & & 0.106325 \\
\hline & $\begin{array}{l}\text { Present-Past: All } \\
\text { systems }\end{array}$ & $\mathrm{A}_{4}$ & 1 & 1 & 1 & & \\
\hline \multirow[t]{3}{*}{2} & $\begin{array}{l}\text { Alignment| } \\
\text { Noun: Present } \\
\text { Progressive }\end{array}$ & & $\begin{array}{l}\text { ALIGNMENT| } \\
\text { Noun: Present } \\
\text { Progressive| } \\
\text { N:PROG: O=So? }\end{array}$ & $\begin{array}{l}\text { ALIGNMENT| } \\
\text { Noun: Present } \\
\text { Progressive| } \\
\text { N:PROG:A=O? }\end{array}$ & $\begin{array}{l}\text { ALIGNMENT| } \\
\text { Noun: Present } \\
\text { Progressive| } \\
\text { N:PROG:A=Sa? }\end{array}$ & $\begin{array}{l}\text { ALIGNMENT| } \\
\text { Noun: Present } \\
\text { Progressive| } \\
\text { N:PROG:Sa=So? }\end{array}$ & 0.093575 \\
\hline & $\begin{array}{l}\text { Noun, Present } \\
\text { progressive: } \\
\text { Tripartite }\end{array}$ & $\mathrm{A}_{5}$ & o & o & o & 1 & 0.03415 \\
\hline & $\begin{array}{l}\text { Noun, Present } \\
\text { progressive: }\end{array}$ & A6 & o & o & 1 & 1 & 0.631175 \\
\hline
\end{tabular}




\begin{tabular}{|c|c|c|c|c|c|c|c|}
\hline Block & Label & ID & Variant (1) & Variant (2) & Variant (3) & Variant (4) & Result \\
\hline & $\begin{array}{l}\text { Nominative- } \\
\text { accusative }\end{array}$ & & & & & & \\
\hline & $\begin{array}{l}\text { Noun, Present } \\
\text { progressive: No } \\
\text { marking }\end{array}$ & $\mathrm{A}_{7}$ & 1 & 1 & 1 & 1 & 0.334675 \\
\hline \multirow[t]{8}{*}{3} & Alignment| & & ALIGNMENT| & ALIGNMENT| & ALIGNMENT| & ALIGNMENT| & \\
\hline & Noun: Simple Past & & Noun: Simple Past| & Noun: Simple & Noun: Simple & Noun: Simple & \\
\hline & & & $\mathrm{N}: \mathrm{PST}: \mathrm{O}=\mathrm{So} ?$ & Past| & Past $\mid$ & Past $\mid$ & \\
\hline & & & & $\mathrm{N}: P S T: A=\mathrm{O} ?$ & $\mathrm{~N}: \mathrm{PST}: \mathrm{A}=\mathrm{Sa} ?$ & $\mathrm{~N}: \mathrm{PST}: \mathrm{Sa}=\mathrm{So} ?$ & \\
\hline & $\begin{array}{l}\text { Noun, Simple past: } \\
\text { Tripartite }\end{array}$ & A8 & o & o & o & 1 & 0.041225 \\
\hline & $\begin{array}{l}\text { Noun, Simple past: } \\
\text { Nominative- } \\
\text { accusative }\end{array}$ & A9 & 0 & o & 1 & 1 & 0.526275 \\
\hline & $\begin{array}{l}\text { Noun, Simple past: } \\
\text { Ergative }\end{array}$ & A10 & 1 & 0 & o & 1 & 0.122925 \\
\hline & $\begin{array}{l}\text { Noun, Simple past: } \\
\text { No marking }\end{array}$ & A11 & 1 & 1 & 1 & 1 & 0.309575 \\
\hline \multirow[t]{6}{*}{4} & Alignment| & & ALIGNMENT| & ALIGNMENT| & ALIGNMENT| & ALIGNMENT| & \\
\hline & Pronoun: Present & & Pronoun: Present & Pronoun: & Pronoun: Present & Pronoun: & \\
\hline & Progressive & & Progressive| & Present & Progressive| & Present & \\
\hline & & & P:PROG: $\mathrm{O}=\mathrm{So} ?$ & $\begin{array}{l}\text { Progressive| } \\
\text { P:PROG:A=O? }\end{array}$ & P:PROG:A=Sa? & $\begin{array}{l}\text { Progressive } \\
\text { P:PROG:Sa=So? }\end{array}$ & \\
\hline & $\begin{array}{l}\text { Pronoun, Present } \\
\text { progressive: } \\
\text { Nominative- } \\
\text { accusative }\end{array}$ & $\mathrm{A}_{13}$ & o & o & 1 & 1 & 0.90245 \\
\hline & $\begin{array}{l}\text { Pronoun, Present } \\
\text { progressive: No } \\
\text { marking }\end{array}$ & $\mathrm{A} 14$ & 1 & 1 & 1 & 1 & 0.09755 \\
\hline \multirow[t]{8}{*}{5} & Alignment|Pronoun: & & ALIGNMENT| & ALIGNMENT| & ALIGNMENT| & ALIGNMENT| & \\
\hline & Simple Past & & Pronoun: & Pronoun: & Pronoun: & Pronoun: & \\
\hline & & & Simple Past| & Simple Past| & Simple Past| & Simple Past| & \\
\hline & & & P:PST: $\mathrm{O}=\mathrm{So} ?$ & $\mathrm{P}: \mathrm{PST}: \mathrm{A}=\mathrm{O} ?$ & $\mathrm{P}: \mathrm{PST}: \mathrm{A}=\mathrm{Sa} ?$ & $\mathrm{P}: \mathrm{PST}: \mathrm{Sa}=\mathrm{So} ?$ & \\
\hline & $\begin{array}{l}\text { Pronoun, Simple } \\
\text { past: Tripartite }\end{array}$ & A15 & o & 0 & o & 1 & 0.035225 \\
\hline & $\begin{array}{l}\text { Pronoun, Simple } \\
\text { past: Nominative- } \\
\text { accusative }\end{array}$ & A16 & o & o & 1 & 1 & 0.77255 \\
\hline & $\begin{array}{l}\text { Pronoun, Simple } \\
\text { past: Ergative }\end{array}$ & A18 & 1 & o & o & 1 & 0.11405 \\
\hline & $\begin{array}{l}\text { Pronoun, Simple } \\
\text { past: No marking }\end{array}$ & A19 & 1 & 1 & 1 & 1 & 0.078175 \\
\hline 6 & $\begin{array}{l}\text { Alignment|Reflexive } \\
\text { pronoun in } \\
\text { transitive clause, A }\end{array}$ & & $\begin{array}{l}\text { ALIGNMENT|Reflexive } \\
\text { Pronoun in trans. } \\
\text { Clause|REFL-ref-A }\end{array}$ & & & & \\
\hline
\end{tabular}




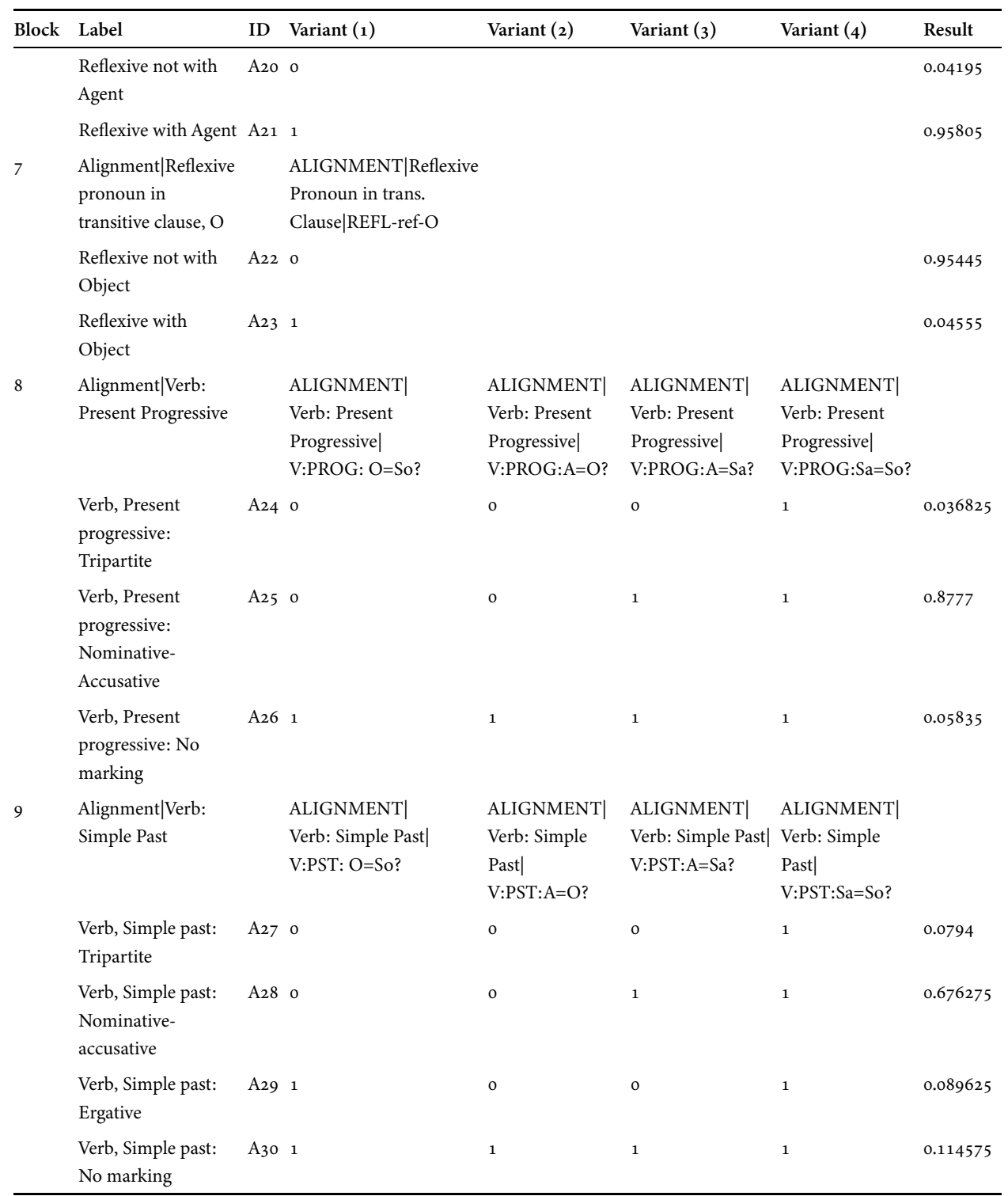

\section{Résumé}

Cet article utilise un model phylogénétique pour reconstruire le système d’alignement de l'indoeuropéen. Nous utilisons des propriétés morphosyntaxiques catégoriques, qui prennent des états tels que «nominatif-accusatif», «actif-statif» ou «ergatif». Par une méthode phylogénétique comparative bayésienne, nous déduisons les taux de transition entre les caractères sur la base d'une représentation phylogénétique des langues dans les données. En utilisant ces taux, 
nous reconstruisons la probabilité de présence de traits à la racine et aux branches de l'indoeuropéen. Nous constatons que le système le plus probable pour le proto-indo-européen est un système nominatif-accusatif, avec de faibles probabilités d'ergativité dans les catégories inférieures dans les hiérarchies grammaticales (noms, temps passé). En utilisant un test de signal phylogénétique, nous constatons que les caractères appartenant à des catégories plus élevées dans les hiérarchies grammaticales montrent une plus grande stabilité phylogénétique que les catégories inférieures dans les hiérarchies. Nous examinons nos résultats par rapport aux théories antérieures sur l'alignement proto-indo-européen ainsi qu’à la typologie générale.

\title{
Zusammenfassung
}

In diesem Artikel wird ein phylogenetisches Modell verwendet, um das Alinierungssystem des Indogermanischen zu rekonstruieren. Die Daten liegen dabei in Form morphosyntaktischer Merkmale vor, die Zustände wie „Nominativ-Akkusativ“, „Aktiv-Stativ“ oder „Ergativ“ annehmen. Mittels einer Bayesschen Standardmethode zum phylogenetischen Vergleich schätzen wir zunächst auf der Grundlage einer phylogenetischen Darstellung der in den Daten vorkommenden Sprachen Übergangsraten zwischen den Merkmalswerten ab. Anhand dieser Raten rekonstruieren wir anschließend Wahrscheinlichkeiten für das Vorhandensein der verschiedenen Merkmale sowohl am Wurzelknoten als auch den intermediären Knoten des indogermanischen Stammbaums. Im Ergebnis ergibt sich als das wahrscheinlichste System für das Proto-Indogermanische ein Nominativ-Akkusativ-System, während der neutralen Markierung und der Ergativität geringere Wahrscheinlichkeiten in denjenigen Kategorien zugeordnet werden (Substantive, Vergangenheitstempus), die in üblichen grammatischen Hierarchien niedriger platziert sind. Bei einem Test des phylogenetischen Signals stellen wir fest, dass Merkmale, die sich auf in grammatikalischen Hierarchien höher platzierte Kategorien beziehen, eine größere phylogenetische Stabilität aufweisen als niedriger stehende Kategorien. Diese Ergebnisse werden abschließend in Bezug zu früheren Theorien zur Alinierung im Indogermanischen sowie zur allgemeinen Typologie gestellt.

\section{Address for correspondence}

\author{
Gerd Carling \\ Department of Linguistic and Phonetics \\ Centre for Languages and Literature \\ Lund University \\ Box 201 \\ 221 oo LUND \\ Sweden \\ gerd.carling@ling.lu.se
}




\section{Co-author information}

Chundra Cathcart

Department of Comparative Language Science

University of Zurich

chundra.cathcart@uzh.ch 